\title{
RESPONSABILIDADE CIVIL POR DANO AMBIENTAL DECORRENTE DO ROMPIMENTO DE BARRAGEM
}

\author{
Jose Geraldo Romanello Bueno ${ }^{1}$ \\ Michely Vargas Delpupo ${ }^{2}$
}

\section{Resumo}

O objetivo deste trabalho é analisar a responsabilidade civil pelo dano ambiental decorrente da ruptura de barragens. Para tanto, será apresentado um breve relato histórico sobre os rompimentos de barragens no mundo. Faz-se ainda, uma análise das legislações de alguns países estrangeiros, no que concerne à responsabilidade civil no âmbito ambiental, com o intuito de proporcionar uma visão sistêmica acerca do atual desenvolvimento da matéria. Além disso, será dado enfoque especial ao estudo dos requisitos da responsabilidade civil ambiental no direito brasileiro, como por exemplo, ação ou omissão, o dano ambiental e o nexo de causalidade. Finalmente, será discutido a respeito da responsabilidade por danos decorrentes do rompimento de barragens no Brasil. Ademais, pela análise dos sistemas de proteção ao meio ambiente realizada no presente trabalho, é possível verificar que o Brasil possui uma legislação bastante moderna, cujo sistema de responsabilização adotado é objetivo, apresentando maior semelhança com o direito norte-americano. Em contrapartida, o Brasil não tem instrumentos para que seja realizada a reparação do dano imediatamente após sua ocorrência. Nesse aspecto, apesar do rigor legislativo, a reparação do dano, no Brasil, é pouco eficaz, devendo ser criados instrumentos executivos para que haja uma tutela mais efetiva.

Palavras-chave: Rompimento de Barragens; Dano Ambiental; Responsabilidade Civil Ambiental; Responsabilidade Objetiva; Desenvolvimento Sustentável.

\section{INTRODUÇÃO}

Não faz muito tempo que o homem passou a se preocupar efetivamente com os recursos naturais. Em passado não muito remoto, vigorava a noção de que os recursos naturais eram ilimitados. O fato é que o homem tem necessidades ilimitadas, enquanto os recursos da natureza são limitados.

Nessa simples análise, residem alguns dos grandes problemas da civilização. As guerras, os conflitos sociais e as revoluções podem ter outro pano de fundo, mas, no âmago, procuram sempre o poder para usufruir

\footnotetext{
${ }^{1}$ Professor de Direito Civil na Universidade Presbiteriana Mackenzie - Campus Campinas. Doutorando em Direito Civil na Universidade de São Paulo - USP.E-mail: gromanello@usp.br

${ }^{2}$ Professora de Direito Civil no Centro Universitário Adventista de São Paulo. Doutoranda em Direito Civl na Pontifícia Universidade Católica de São Paulo - PUC/SP.E-mail: michelydelpupo@terra.com.br
} 
dos bens naturais. Por outro lado, a manutenção da natureza, plantas e animais é questão de vida ou morte. Aos poucos, os governos foram sendo conscientizados da necessidade de proteção da Terra. Nas diversas áreas de atuação e de conhecimento, desenvolvem-se esforços para obtenção de métodos a fim de compatibilizar o crescimento com a preservação dos recursos naturais.

Por outro lado, o progresso e as necessidades da vida não permitem que os bens naturais sejam considerados ilimitados. A grande questão em matéria de direito ambiental é equacionar o ponto de equilíbrio que permita gerar bens para o homem e, ao mesmo tempo, preservar os recursos naturais para as futuras gerações.

Nesse sentido, a humanidade enfrenta problemas gravíssimos de poluição de águas, contaminação do solo e do ar. Assim, verifica-se que a luta é contínua em prol de um meio ambiente sustentável. Para tanto, criou-se instituto jurídico da responsabilidade civil por danos ambientais, que visa coibir ações degradatórias e recuperar o meio ambiente degradado. Dessa forma, na busca de maior efetividade na proteção ambiental, verifica-se que cada país vem adotando um sistema de responsabilização próprio, visando a um desenvolvimento sustentável.

O objetivo do presente trabalho é analisar a responsabilidade civil por dano ambiental decorrente da ruptura de barragens. Para tanto, será apresentado um breve relato histórico sobre os rompimentos de barragens no mundo. Além disso, será feita uma análise das legislações de alguns países da América do Norte, União Europeia e América Latina, no que concerne à responsabilidade civil no âmbito ambiental, com o intuito de proporcionar uma visão sistêmica acerca do atual desenvolvimento da matéria.

Ademais, será dado enfoque especial ao estudo dos requisitos da responsabilidade civil ambiental no direito brasileiro, como por exemplo, ação ou omissão, o dano ambiental e o nexo de causalidade. Finalmente, discutir-se-á a respeito da responsabilidade por danos decorrentes do rompimento de barragens no Brasil.

A metodologia utilizada neste trabalho foi estritamente a consulta bibliográfica de livros e revistas mais atuais disponíveis sobre o tema, tanto na legislação pátria quanto na estrangeira. Além disso, utiliza-se como fonte de pesquisa artigos publicados na internet e análise de jurisprudência sobre o assunto.

\section{BREVE HISTÓRICO SOBRE OS ROMPIMENTOS DE BARRAGENS NO MUNDO}

Para melhor compreensão do estudo, é necessário apresentar um breve relato de casos sobre rompimento de barragens no mundo e a gravidade dos acidentes desta natureza, envolvendo em geral, prejuízos ambientais e perdas de vidas humanas.

Um dos grandes acidentes sobre a ruptura de barragens ocorreu há mais de 100 anos, em 1 de junho de 1889, na cidade de Johnstown, na Pennsylvania, EUA. Naquela época, a ruptura da barragem de terra gerou uma onda cheia que se propagou com uma altura de mais de $10 \mathrm{~m}$ e a uma velocidade de cerca de $15 \mathrm{~m} / \mathrm{s}$ em direção à cidade de Johnstown. Este acidente provocou mais de 2.200 vítimas fatais e milhares de outras pessoas perderem 
todos os bens que possuíam. A Figura 1 mostra a beleza da cidade de Johnstown, localizada cerca de $20 \mathrm{~km} \mathrm{a}$ jusante da barragem. Em contrapartida, a Figura 2 mostra como ficou a cidade após a passagem da onda.

Figura 1 - Cidade de Johnstown antes da rotura da barragem

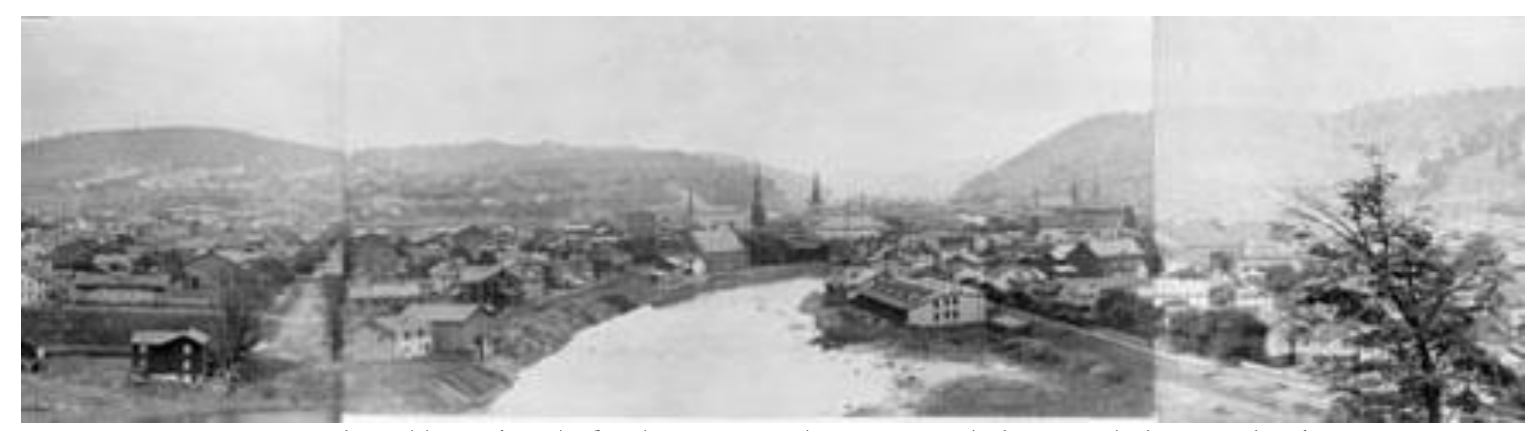

Fonte: <http://w3.ualg.pt/ jdias/GEOLAMB/GAn_Casos/Johnstown/Johnstown.html>

Figura 2 - Cidade de Johnstown após a passagem da onda de cheia

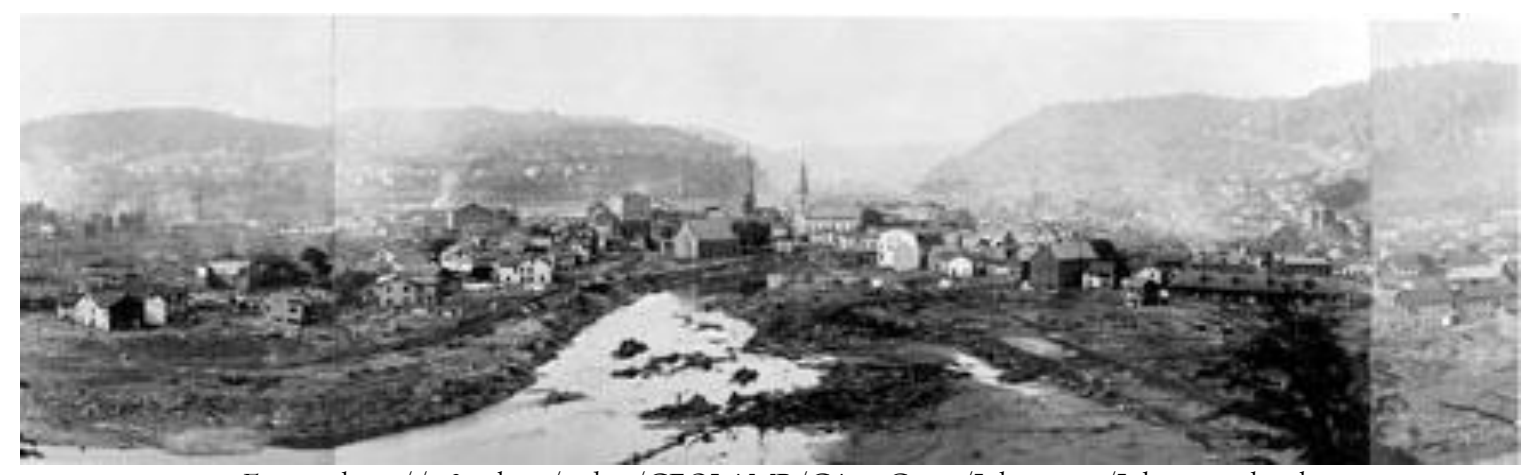

Fonte: <http://w3.ualg.pt/ jdias/GEOLAMB/GAn_Casos/Johnstown/Johnstown.html>

Posteriormente, em 12 de março de 1928, ocorreu a ruptura da barragem de St. Francis, perto de Los Angeles, Califórnia, EUA, tendo vitimado 600 pessoas. O enchimento do lago criado pela barragem teve início em 1 de março de 1926, verificando-se as primeiras infiltrações cerca de um mês depois (CARMO, 2013, p. 448).

Em 7 de março de 1928, com o nível da água já muito próximo da base superfície, foram detectadas várias fendas e infiltrações em ambos os encontros da barragem. A ruptura da barragem ocorreu cinco dias depois, gerando uma onda com cerca de $43 \mathrm{~m}$ de altura que se propagou para jusante, atingindo cinco minutos após a ruptura uma infraestrutura situada a $2.4 \mathrm{~km}$, com uma velocidade de $29 \mathrm{~km} / \mathrm{h}$ e uma altura de $37 \mathrm{~m}$, vitimando aí 64 trabalhadores. Apenas 60 metros de secção central da barragem permaneceram "de pé" após o esvaziamento do lago. A Figura 3 mostra a barragem como era e o que dela restou depois o acontecimento (Figura 4). Apenas 60 metros de secção central da barragem permaneceram “de pé” após o esvaziamento do lago. 
Figura 3 - Vista frontal da barragem de St. Francis

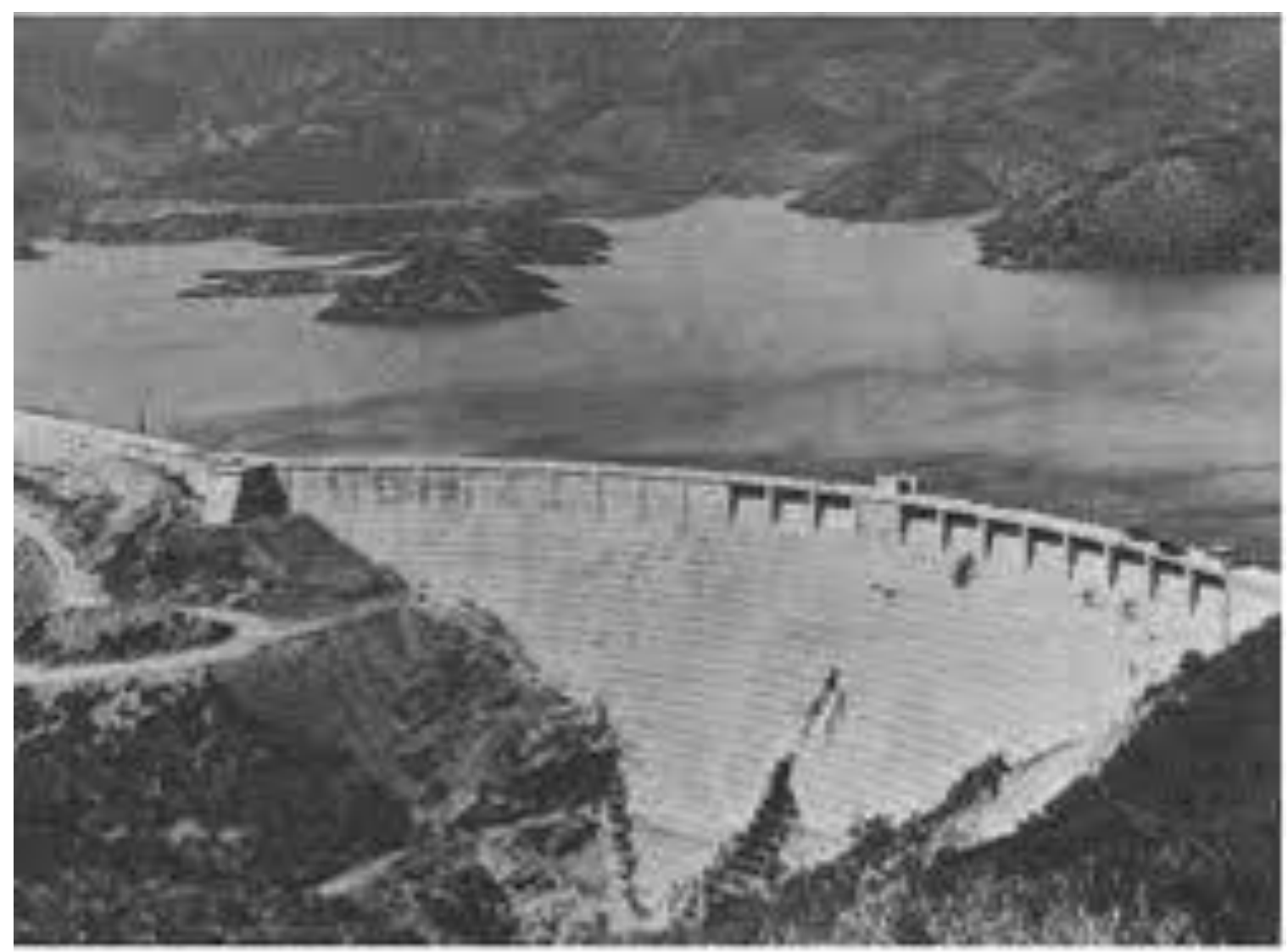

Fonte: <http://www.uc.pt/fluc/depgeo/Publicacoes/livro_homenagem_FRebelo/441_461>

Figura 4 - Restos da barragem após o acidente

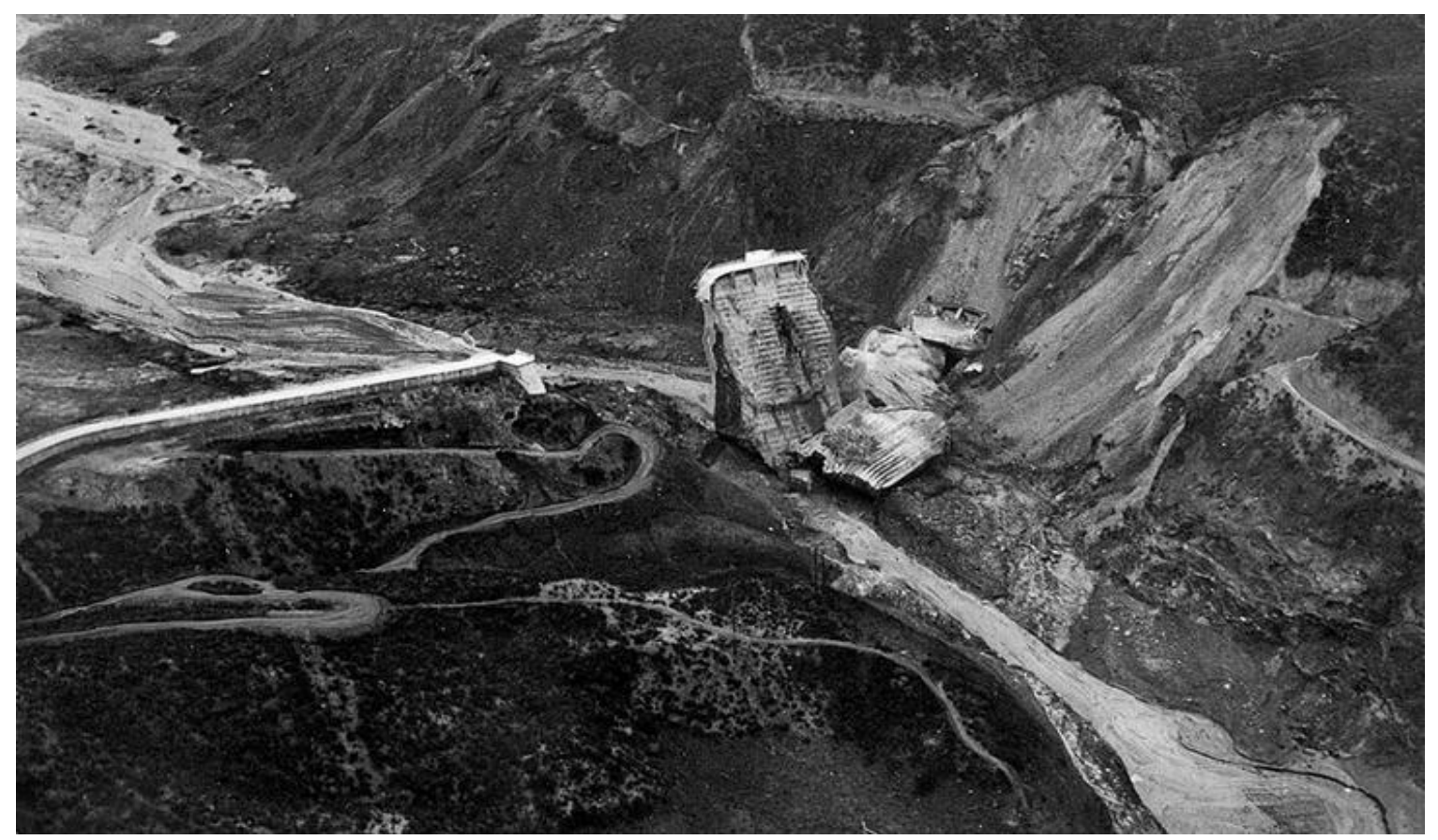

Fonte: <http://www.uc.pt/fluc/depgeo/Publicacoes/livro_homenagem_FRebelo/441_461> 
Em seguida, no dia 02 de dezembro de 1959, ocorreu a ruptura da barragem de Malpasset, construída entre os anos de 1952 e 1954 no rio Reyran, na França. A barragem de Malpasset, como ficou conhecida, tinha como principais objetivos o abastecimento de água para o consumo da população e a irrigação de plantios (CARMO, 2013, p. 449-450).

A barragem de Malpasset literalmente 'explodiu', descarregando 50 milhões de toneladas de água que geraram, na fase inicial, uma onda com 50 metros de altura e propagou-se com uma velocidade de $70 \mathrm{~km} / \mathrm{h}$. Essa onda transportou consigo enormes pedaços de blocos de betume para o vale a jusante, parte deles pesando cerca de 600 toneladas. Alguns desses restos podiam ser vistos ao longo da autoestrada, a mais de um quilômetro da sua localização inicial. Poucos minutos após o colapso, 53 casas já haviam sido destruídas e 120 pessoas morreram, somente no vale do Reyran.

Com o rompimento desta barragem, a estimativa é que 423 pessoas morreram, entre as quais 135 eram crianças com idades inferiores a 15 anos; este desastre deixou ainda 79 crianças órfãs. A Figura 5 mostra uma imagem da secção do vale onde se localizava a barragem de Malpasset.

\section{Figura 5 - Secção do vale onde se localizava a barragem de Malpasset}

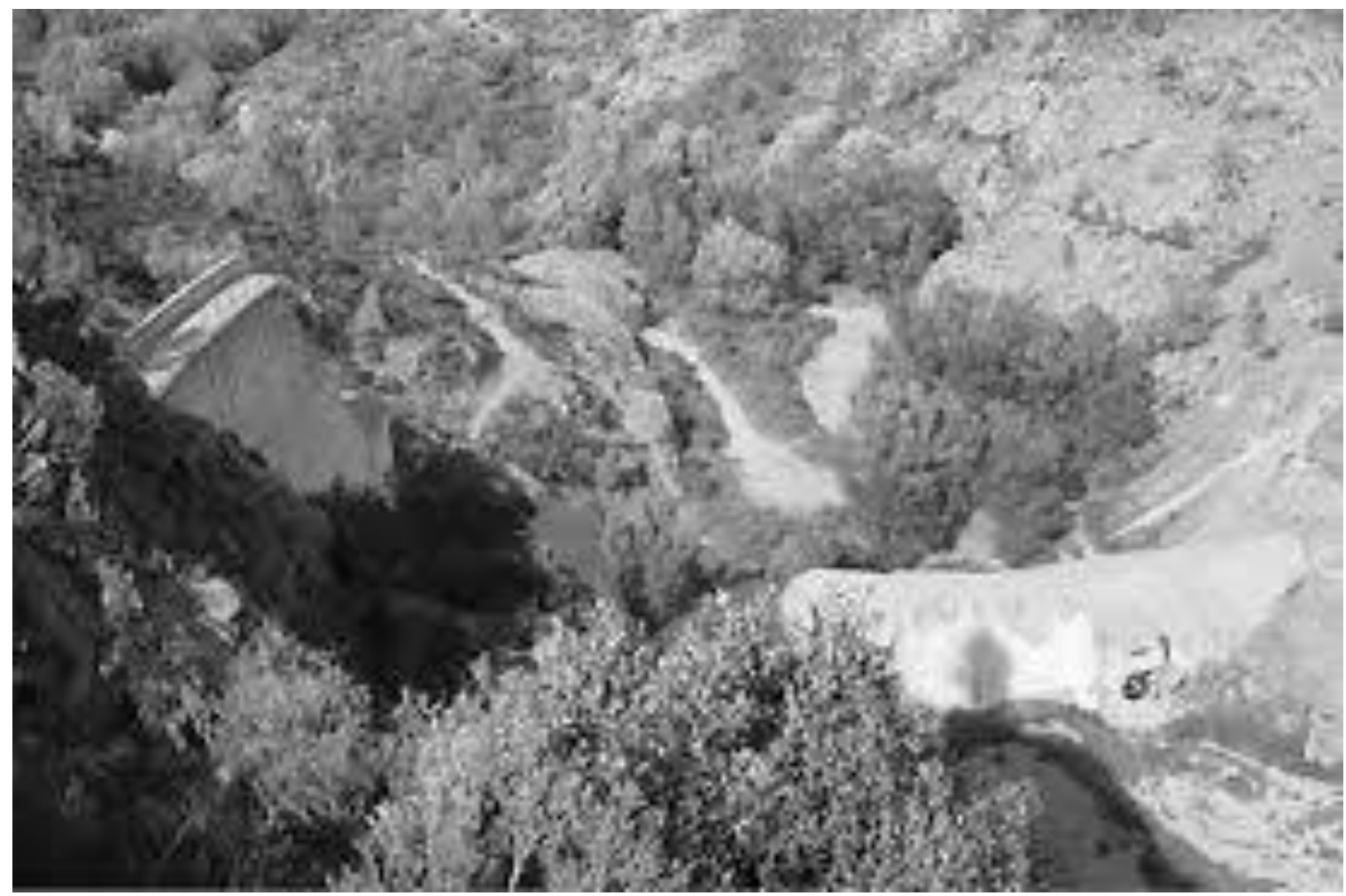

Fonte: $<$ http://www.uc.pt/fluc/depgeo/Publicacoes/livro_homenagem_FRebelo/441_461>

Posteriormente, no dia 9 de outubro de 1963 ocorreu o deslizamento da barragem de água construída no rio Vajont, na Itália. Em poucos minutos, os 115 milhões de metros cúbicos de água bloqueou completamente 
o vale num comprimento de aproximadamente 2.500 metros. A água da represa atingiu a aldeia de Casso, de Longarone, Pirago, Villanova, Rivalta e Fae, na Itália, destruindo-as completamente. Neste acidente perderam-se cerca de 2.500 vidas (CARMO, 2013, p. 449-450). A Figura 6 mostra a barragem e as margens do lago antes e após (figura 7) o deslizamento da encosta.

\section{Figura 6 - Barragem de Vajont - Vista antes do acidente}

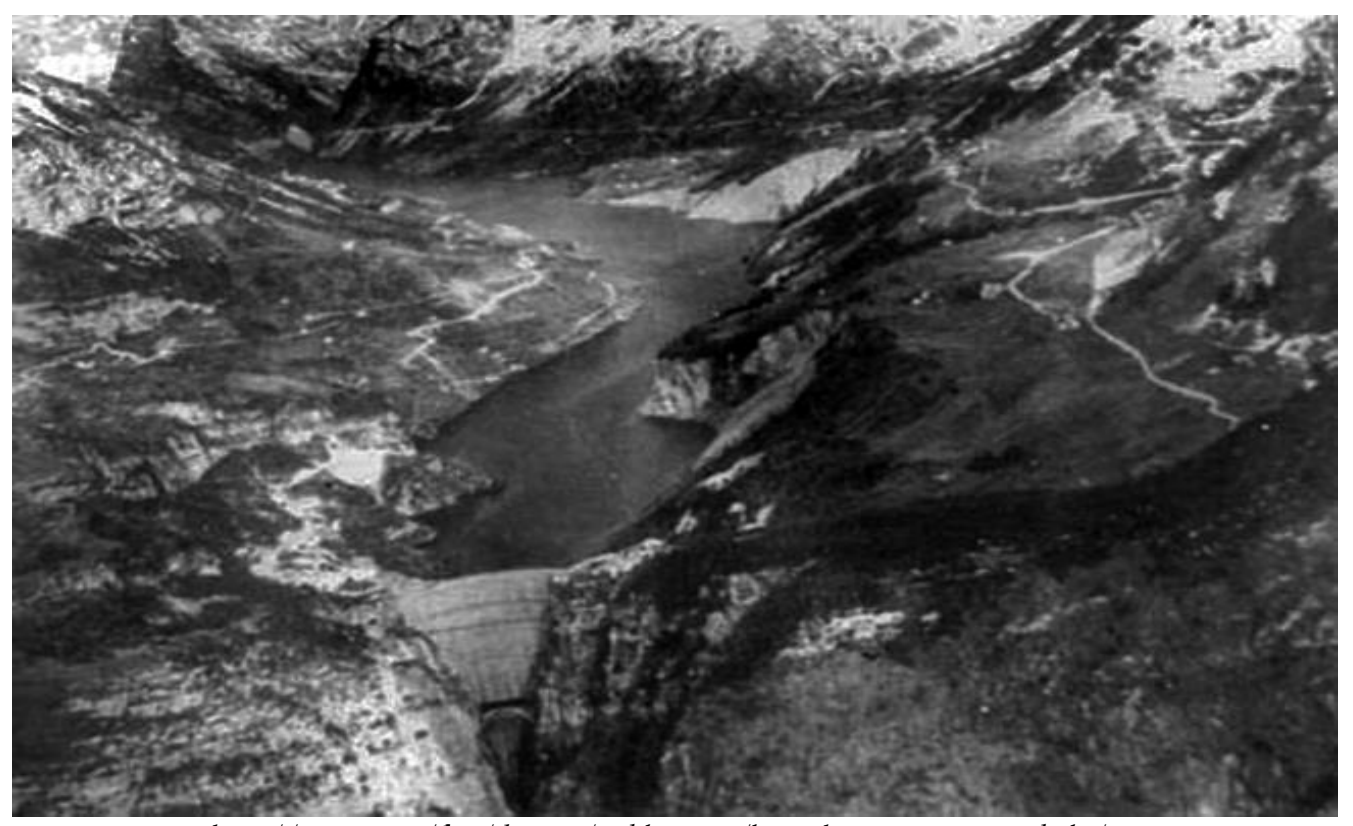

Fonte: <http://www.uc.pt/fluc/depgeo/Publicacoes/livro_homenagem_FRebelo/441_461>

Figura 7 - Situação em que ficou a barragem de Vajont, na Itália, após o deslizamento da encosta

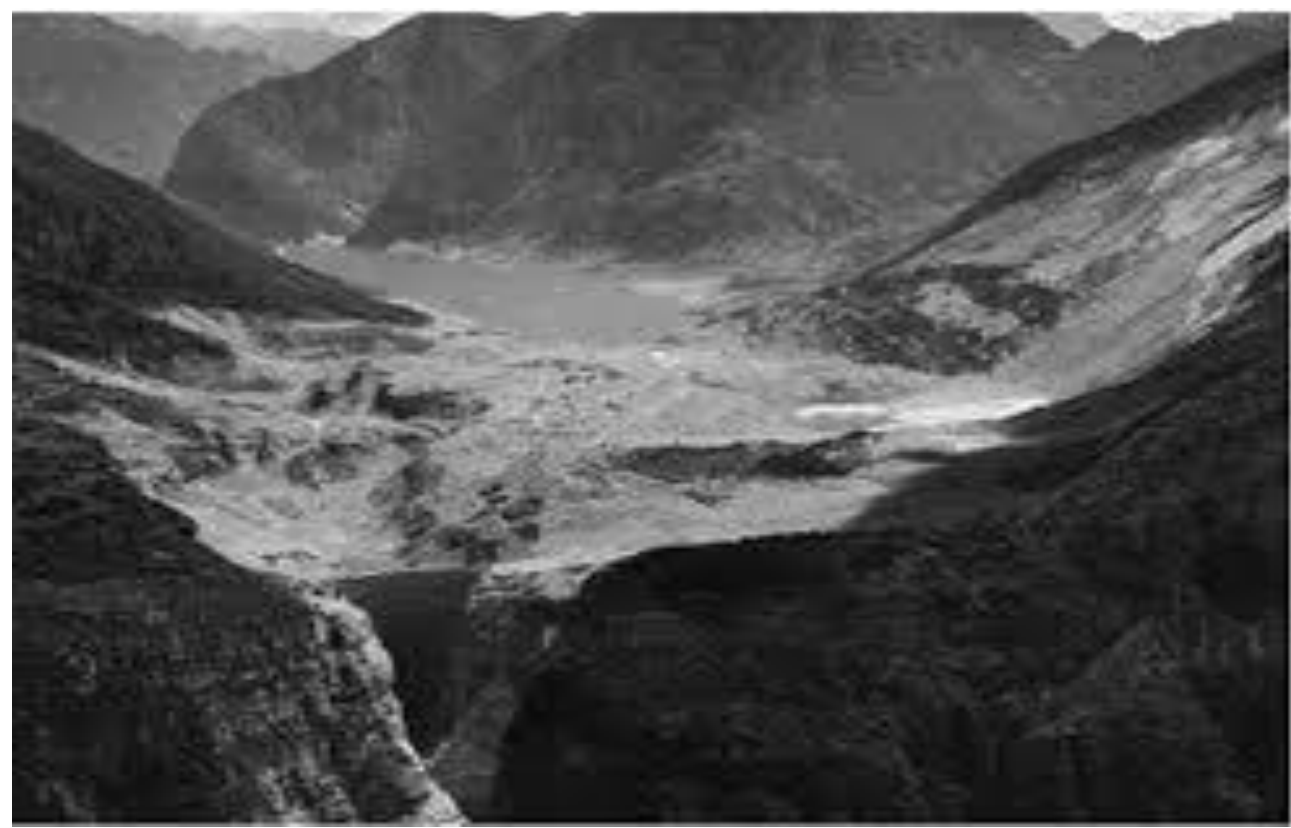

Fonte: <http://www.uc.pt/fluc/depgeo/Publicacoes/livro_homenagem_FRebelo/441_461> 


\section{Quaestio Iuris}

Após todas essas tragédias ambientais, no dia 5 de junho de 1976, ocorreu a ruptura da barragem de Teton, Idaho, EUA. Este acidente resultou em grande destruição ambiental e num elevado número de vítimas. A principal causa do rompimento da barragem foi devida à menor qualidade do solo de fundação. A composição da rocha de fundação, bem como o material usado na construção da barragem, permitia infiltrações. Por outro lado, os testes preliminares efetuados identificaram fissuras na rocha de fundação que não foram devidamente corrigidas. Apesar dos riscos, decidiu-se continuar com a construção da barragem (CARMO, 2013, p. 449-451). A Figura 8 mostra a barragem de Teton e o respectivo descarregador antes do acidente e a Figura 9 mostra o local onde se situavam os sistemas barragem, após a ruptura.

\section{Figura 8 - vista frontal da barragem de Teton e do descarregador}

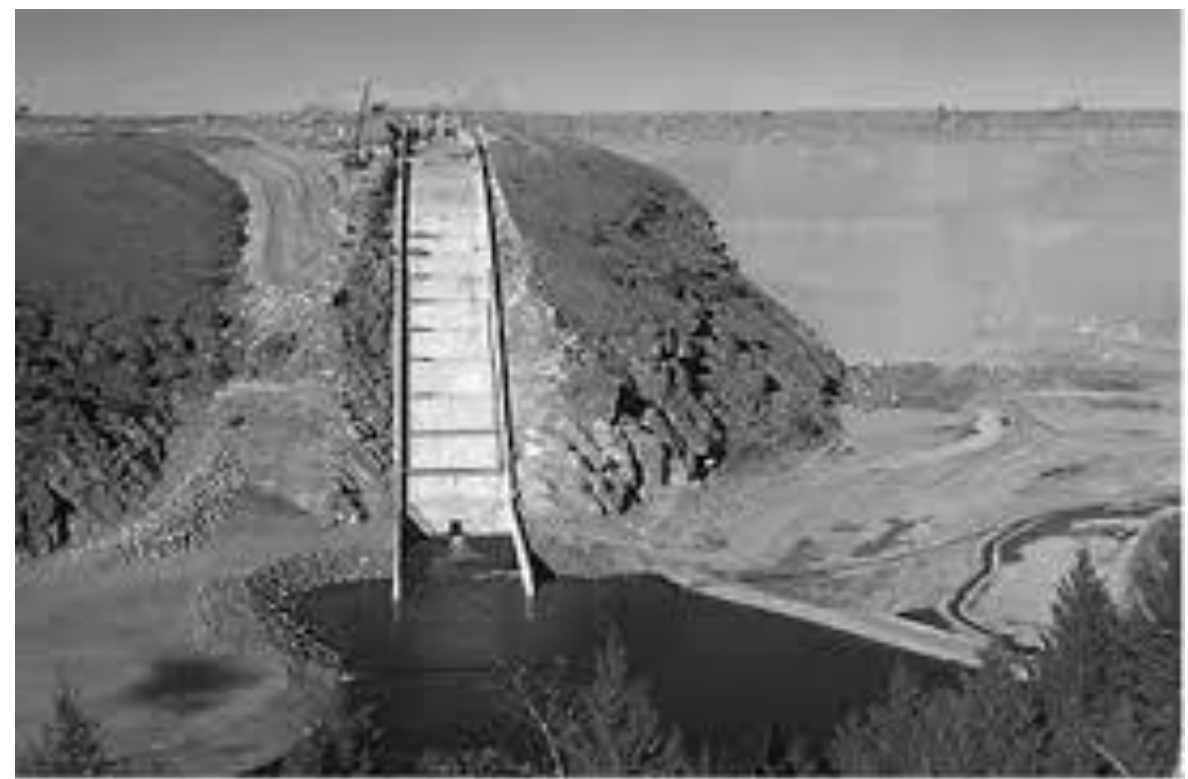

Fonte: <http://www.uc.pt/fluc/depgeo/Publicacoes/livro_homenagem_FRebelo/441_461>

Figura 9 - Local da albufeira após a rotura

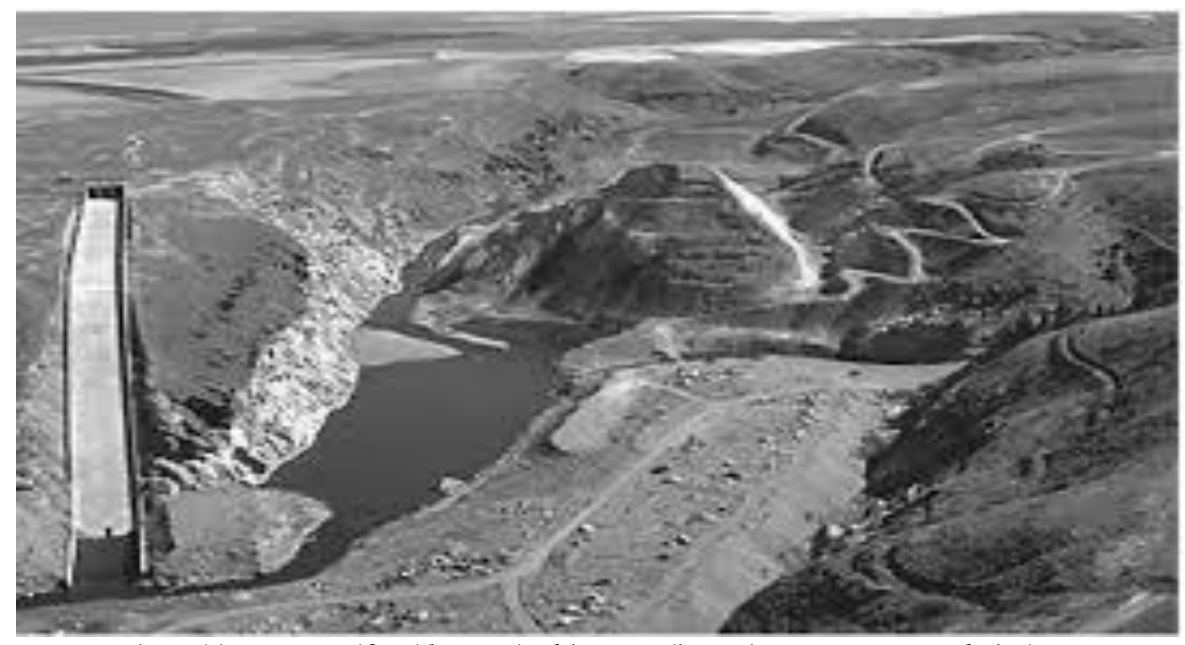

Fonte: <http://www.uc.pt/fluc/depgeo/Publicacoes/livro_homenagem_FRebelo/441_461> 
Recentemente, em 05 novembro de 2015, a barragem de Fundão, de propriedade da Sociedade Anônima Samarco Mineração S.A., localizada no Município de Mariana, em Minas Gerais, foi alvo de um rompimento, que acarretou a erosão da barragem de Santarém e resultou no derramamento de aproximadamente de 60 milhões de metros cúbicos de rejeitos de mineração no vale do rio Doce. A figura 10 mostra o distrito de Bento Rodrigues antes e após a erosão causada pelo rompimento da barragem.

\section{Figura 10 - Distrito de Bento Rodrigues antes e após a erosão causada pelo rompimento da}

\section{barragem}
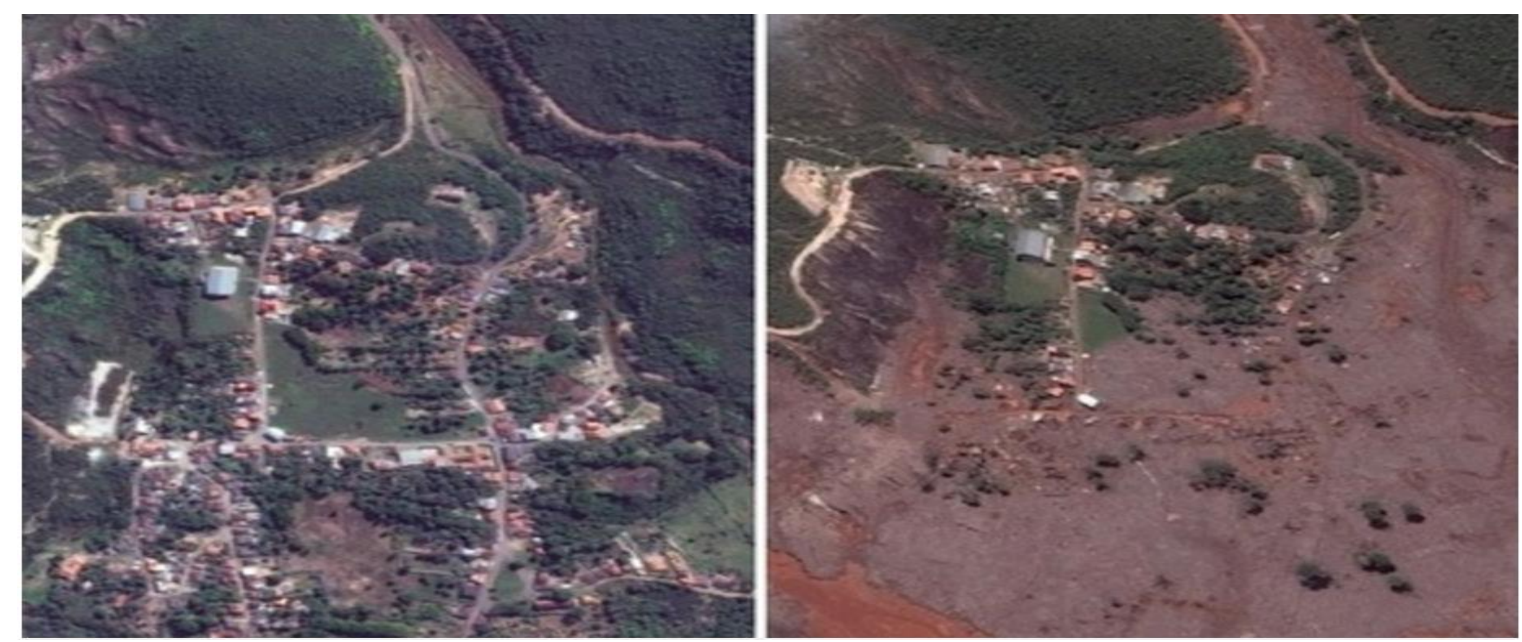

Fonte: <http://cbhvelhas.org.br/noticias/danos-causados-pelo-rompimento-da-barragem-de-mariana-preocupam-o-cbh-rio-dasvelhas/>

A lama formada por esses rejeitos, era composta de resíduos de minério de ferro, contendo altos níveis de metais pesados e outros produtos químicos tóxicos, e atingiu diretamente 663 quilômetros de corpos hídricos, carreando resíduos até a foz do rio Doce, no oceano Atlântico, já no Estado do Espírito Santo, o que qualifica o episódio como o maior acidente da História, com barragens de rejeitos e, o maior desastre ambiental já ocorrido no Brasil, conforme podemos ver na figura 11 e 12.

\section{Figura 11 - Rejeitos da barragem de Bento Rodrigues, Mariana - MG}

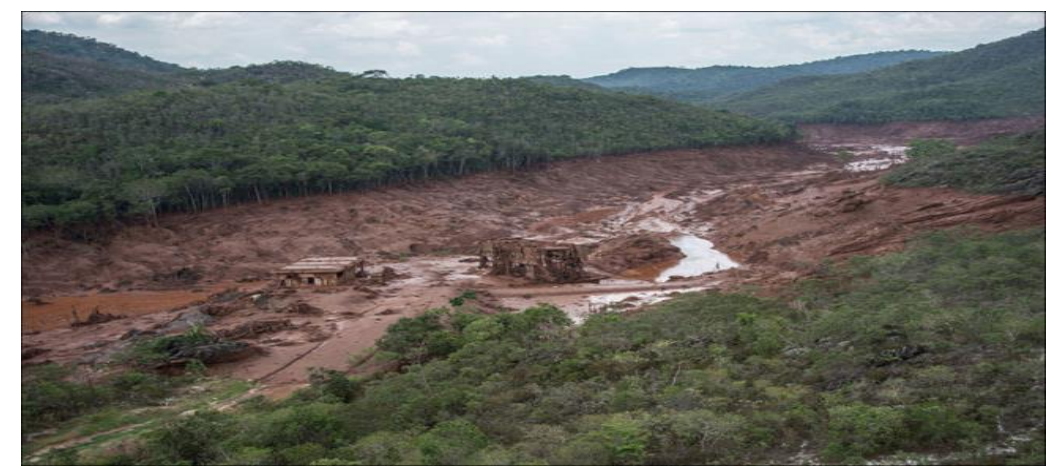

Fonte: <http://obutecodanet.ig.com.br/index.php/2015/11/16/fotos-incriveis-que-mostram-a-destruicao-provocada-pelorompimento-da-barragem-em-mariana/> 
Figura 12 - Desalojamento da população do Distrito de Bento Rodrigues

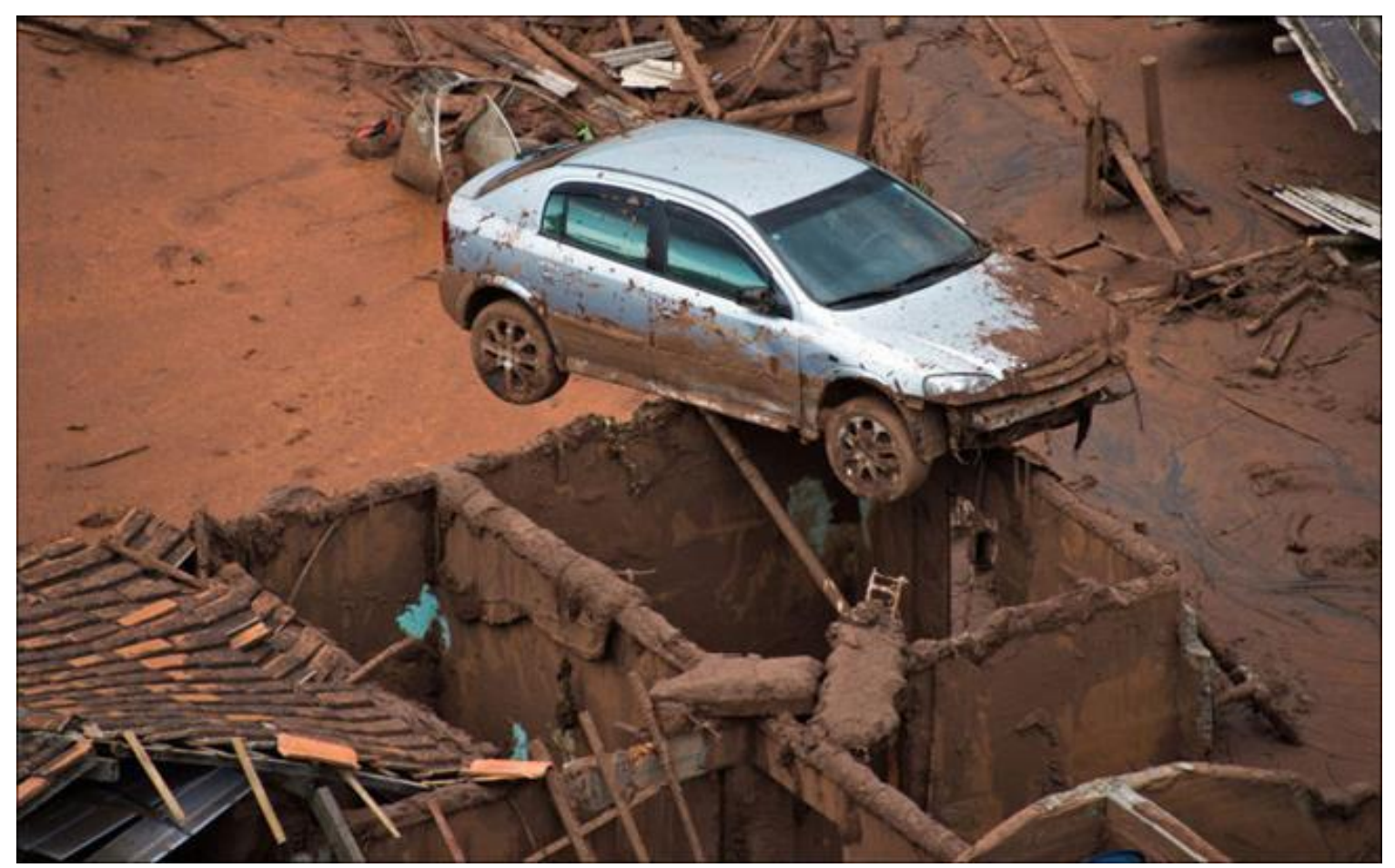

Fonte: <http://obutecodanet.ig.com.br/index.php/2015/11/16/fotos-incriveis-que-mostram-a-destruicao-provocada-pelorompimento-da-barragem-em-mariana/>

O laudo técnico preliminar divulgado pelo Instituto Brasileiro do Meio Ambiente e dos Recursos Naturais Renováveis (IBAMA), em dezembro de 2015, constatou que o desastre resultou, dentre outras coisas, na morte de trabalhadores da Samarco e de moradores das comunidades afetadas; no desalojamento de populações (figura 13); na devastação de localidades, com a perda de estruturas públicas e privadas; na destruição de 1.469 hectares de vegetação, incluindo Áreas de Preservação Permanente (APP); na mortandade de biodiversidade aquática e fauna terrestre; na perda e na fragmentação de habitats; na interrupção da pesca por tempo indeterminado; na interrupção do turismo; na alteração dos padrões de qualidade da água doce, salobra e salgada; na interrupção do abastecimento de água e na dificuldade de geração de energia elétrica pelas hidrelétricas atingidas (Instituto Brasileiro do Meio Ambiente e dos Recursos Naturais Renováveis, 2015, p. 4). 
Figura 13 - Cavalo imerso na lama

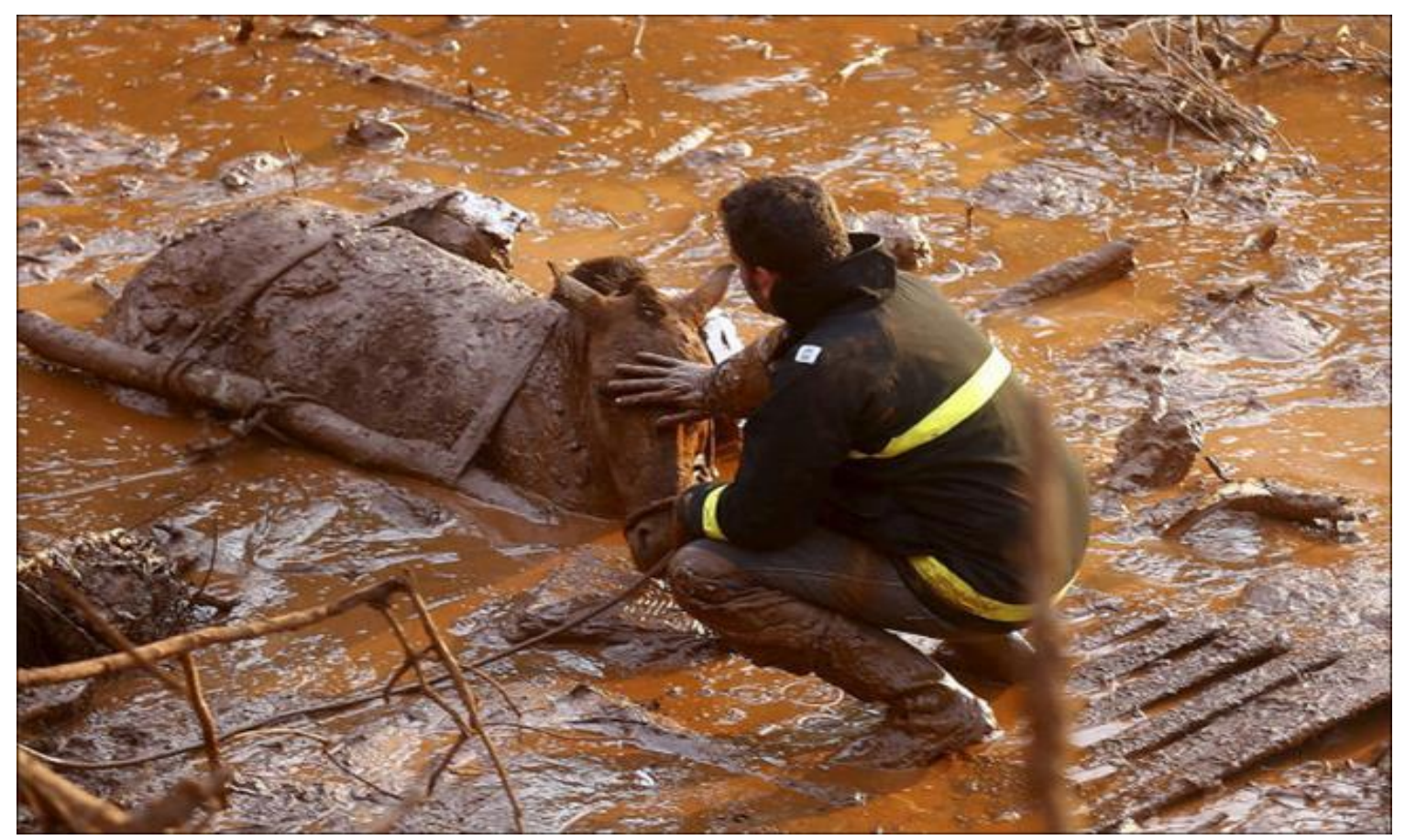

Fonte: <http://obutecodanet.ig.com.br/index.php/2015/11/16/fotos-incriveis-que-mostram-a-destruicao-provocada-pelorompimento-da-barragem-em-mariana/>

Figura 14 - Cachorro sendo retirado da lama da barrage de Bento Rodrigues, Mariana, MG

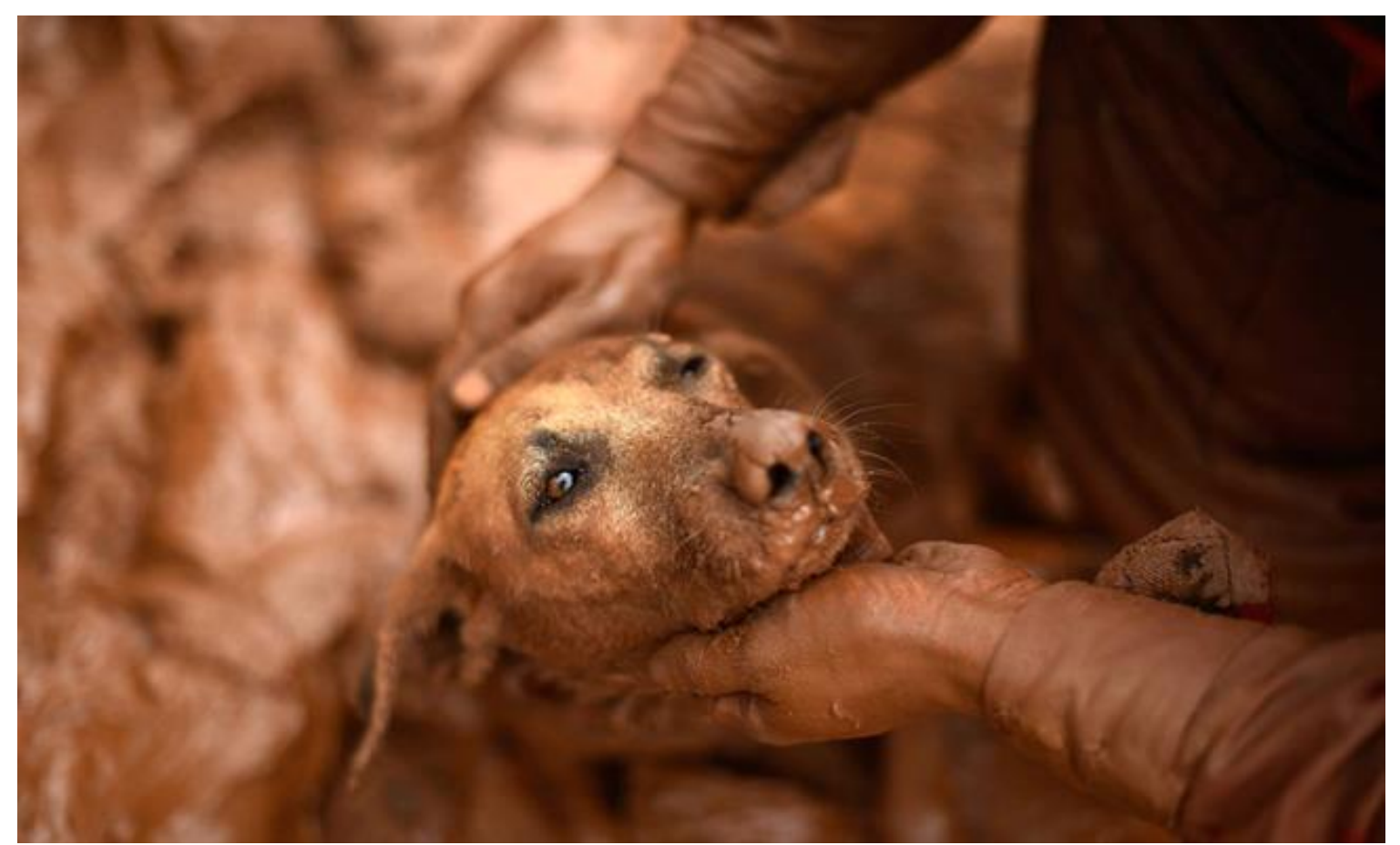

Fonte: <http://obutecodanet.ig.com.br/index.php/2015/11/16/fotos-incriveis-que-mostram-a-destruicao-provocada-pelorompimento-da-barragem-em-mariana/> 
O IBAMA aplicou multas preliminares no valor de 250 milhões de reais à Samarco. Além disso, a mineradora deverá arcar ainda com a indenização às pessoas afetadas e com os custos de reconstrução da região atingida. Além disso, o Poder Judiciário bloqueou 300 milhões de reais da conta da Samarco, a fim de garantir esses pagamentos.

\section{A RESPONSABILIDADE CIVIL POR DANO AMBIENTAL NA LEGISLAÇÃO ESTRANGEIRA}

Apresenta-se a seguir um breve panorama referente à questão da responsabilidade civil pelo dano ambiental em alguns países estrangeiros. Foram selecionados alguns países desenvolvidos, pois já têm melhor equacionada a questão ambiental. A maior parte deles promulgou novas Constituições Políticas nos últimos 25 anos, as quais passaram a incorporar diversos dispositivos relativos à proteção ambiental e à promoção de modelos de desenvolvimento sustentável.

\section{$\mathrm{Na}$ América do Norte}

\section{$\underline{\text { Estados Unidos }}$}

A responsabilidade civil no sistema legal norte-americano, baseado na Common Law, é regulamentada pelo Comprehensive Environmental Response, Compensation, and Liability Act (Cercla) 3 , de 1980, que possui emendas advindas do Superfund Amendments and Reauthorization Act (SARA), de 1986.

Segundo Baracho Júnior o texto do CERCLA, que inclui os dispositivos do SARA, autoriza o Environmental Protection Agency (EPA) a eliminar o lançamento ou ameaça de lançamento de substâncias lesivas ao meio ambiente (2000, p. 307-308):

O lançamento (release), de acordo com o $\$ 101(22)$ do Cercla, significa qualquer derramamento (spilling), vazamento (leaking), depósito (dumping) ou descarte (disposing) no meio ambiente. Substâncias lesivas ao meio ambiente são aquelas designadas pelas seções 307 (a) e 311 (b)(2)(A) do Clean Water Act, pela seção 112 do Clean Air Act, pela seção 3001 do Resource Conservation and Recovery Act, pela seção 7 do Toxic Substances Control Act e pela seção 102 do próprio Cercla. O Cercla não requer níveis especiais de concentração de poluentes para deflagrar a atuação da Environmental Protection Agency (EPA). Assim, qualquer vestígio de substâncias lesivas ao meio ambiente é suficiente para ser considerado como um lançamento.

O sistema legal norte-americano CERCLA possui um sistema para identificar os locais onde ocorrem lançamentos de resíduos perigosos no ambiente ou onde podem vir a ocorrer, sendo que os locais com maior nível de contaminação são inseridos em uma lista denominada National Priority List (NPL).

\footnotetext{
${ }^{3}$ Responsabilidade Compreensiva Ambiental, Compensação e Ato de Responsabilidade.
} 
A responsabilidade civil nos Estados Unidos possui três características: é solidária, objetiva e ainda pode ser retroativa, uma vez que se pode imputar a responsabilidade por atos praticados previamente à edição do CERCLA.

Sobre a responsabilidade solidária neste instituto, Lemos esclarece (2008, p. 87):

De acordo com a seção 107 (a) do Cercla, com as alterações do Sara, são responsáveis civilmente o proprietário ou usuário atual da área em que são lançados os poluentes, o proprietário ou usuário ao tempo em que ocorreu o lançamento e também o responsável pela geração, lançamento ou transporte de substância lesiva. Assim, temos o sistema de responsabilidade civil solidária, podendo-se imputar a responsabilidade a qualquer dessas pessoas ou a todas.

Faz-se necessário apresentar um breve relato acerca das excludentes de responsabilidade, previstas na seção 107 (b) do CERCLA, quais sejam: Act of God, Act of war e Act of Third Part. A primeira, "Ato de Deus", diz respeito a eventos considerados força da natureza, tais como, terremotos, inundações, tempestades. A segunda, "Ato de Guerra", exige a existência de um estado de guerra. A última excludente, considerada "ato de terceiro", quando não se tratar de preposto ou empregado e ainda quando não houver qualquer relação contratual com aquele a quem se imputa a responsabilidade. Deve ainda ser comprovado que foram tomadas as devidas precauções para que não ocorresse dano ao meio ambiente.

A terceira excludente pode ser alegada ainda no caso de innocent purchase se o comprador tiver adquirido a propriedade após o lançamento das substâncias e comprove que não sabia e não tinha razões para ter conhecimento do fato, passando, nesse caso, a responsabilidade a ser do vendedor. Da mesma forma ocorre no caso de propriedade recebida por herança ou doação.

Por fim, cumpre destacar que a responsabilidade civil ambiental nos Estados Unidos possui o caráter compensatório e preventivo, conforme afirma Carol Adaire Jones (1996, p. 18):

[...] visa compensar o público pelo custo social total imposto por danos aos recursos naturais - não apenas por perdas provenientes do uso comercial dos recursos. Além disso, ao tornar as partes envolvidas responsáveis pelo custo social dos acidentes, o sistema proporciona incentivos às empresas para que tomem precauções a fim de prevenir danos ao meio ambiente.

Sobre a reparação dos bens ambientais, Leite acrescenta (2011, p. 214):

No direito norte-americano, através do $₫ 311$ do Federal water Pollution Act (Clean Air $A c t$ ), foi adotado o princípio de que a lesão aos recursos naturais deve ser reparada na situação anterior por meio de recomposição, restaurando, substituindo ou adquirindo o equivalente dos recursos naturais lesados. Esta regra foi depois adotada em várias outras normas federais, assim como o Comprehensive Environmental Response and Liability Act (Cercla), \$307, e o Oil Pollution Act (OPA), \$1.006.

Outro exemplo que pode ser utilizado como paradigma são as presunções inseridas no modelo americano, pelo qual há um alcance a todos aqueles considerados potencialmente responsáveis pelo dano, mesmo que estranhos a este, gerando uma situação concreta de rompimento com o nexo de causalidade, que implicará na presunção de causalidade (CATALÁ, 1998, p. 252). 


\section{Canadá}

No Canadá a elaboração de normas ambientais compete aos Ministérios voltados à proteção do público e à qualidade do meio ambiente. Em alguns casos, como nos programas ambientais e nos procedimentos de licenciamento de instalações industriais, as metas de redução da poluição são objeto de negociações entre as indústrias e as autoridades administrativas envolvidas, nas quais a participação do público é bastante reduzida.

Em Quebec a Lei sobre a Qualidade do Meio Ambiente (Loi sur la Qualité de l'Environnement - LQE) obriga o Ministério do Meio Ambiente local a publicar no Diário Oficial todo projeto de regulamento ambiental e a tomar conhecimento de toda objeção formulada por escrito dentro do prazo de 60 dias, para que qualquer cidadão possa ter condições de apresentar suas objeções ou comentários .

Em relação à implantação de empreendimentos e projetos de maior porte o sistema canadense prevê a participação do público em processo prévio de avaliação e exame dos impactos ambientais. Após comunicar ao Ministério do Meio Ambiente sobre o projeto que deseja implantar, o empreendedor recebe diretivas que estabelecem todos os pontos a serem abordados em seu estudo, que deve apresentar também medidas destinadas a prevenir os impactos negativos. Após aprovado pelo Ministério, o Estudo de Impacto Ambiental e um resumo simplificado são colocados à disposição do público por um período de 45 dias, durante a qual qualquer pessoa ou entidade pode requisitar a realização de uma audiência pública, apresentando os motivos pelos quais o público deveria ser melhor informado e consultado sobre o projeto. O Ministro do Meio Ambiente somente recusará a realização da audiência caso entenda serem frívolos os motivos apresentados. Após a determinação ministerial, o órgão responsável pela audiência - Bureau d'Audiences Publiques sur l'Environnement - tem o prazo de quatro meses para realizá-la e apresentar um relatório ao Conselho de Ministros - cujas conclusões, todavia, não vinculam o Conselho, que tem, assim, a última palavra quanto à realização ou não do projeto, podendo até mesmo sugerir modificações ${ }^{5}$.

O sistema de responsabilização ambiental canadense ainda segue o regime comum previsto no seu Código Civil, que é baseado na responsabilidade subjetiva. Exige-se, portanto, que a vítima do dano ambiental prove sua ocorrência, a culpa do responsável e o nexo causal entre a ação culposa e o dano. Não obstante, a LQE confere a todos os direitos à qualidade do meio ambiente, à sua proteção e à salvaguarda das espécies vivas que ali habitem, prevendo a concessão de injunção judicial pela Corte Superior para evitar toda ação ou operação passível de ameaçar direitos (PORFÍRIO JUNIOR, 2002, p. 80).

\footnotetext{
${ }^{4}$ Quebec. Loi sur la Qualité de l'Environnement - LQE. Disponível em: <http://legisquebec.gouv.qc.ca/fr/showDoc/cs/Q2? \&digest=>. Acesso em: 20 abr. 2016.
} 
Para tanto, o demandante deverá provar que frequenta o local onde ocorre a atividade poluidora e que o suposto poluidor opera em desacordo com a LQE, em razão de emissão de substâncias proibidas ou emissões acima dos limites fixados nos regulamentos, ou ainda porque tais emissões sejam passíveis de trazer ameaças à vida, à saúde, ao bem-estar ou ao conforto dos seres humanos ou de causar dano ao meio ambiente.

Deve-se ressaltar, todavia, a limitação do alcance da lei, pois o Judiciário não pode expedir a injunção caso o funcionamento das instalações tenha sido regularmente autorizado pela Administração, nos termos da LQE e de seus regulamentos, a menos que tal funcionamento não esteja em conformidade com a autorização. Além disso, a injunção também não pode ser concedida em relação às atividades que já estejam incluídas em algum programa ou plano de redução de poluição.

\section{Na União Europeia}

Em relação à responsabilidade civil por dano ambiental, destaca-se a Convenção Europeia sobre Responsabilidade Civil por Danos resultantes de Atividades Prejudiciais ao Meio Ambiente ou Convenção de Lugano, celebrada em 1993 e depositada junto ao Conselho Europeu. Trata-se de um instrumento jurídico internacional relativo à gestão de substâncias perigosas e instalações para o tratamento de resíduos. A importância da Convenção de Lugano advém do fato de que ela é considerada a primeira convenção internacional cujo objeto é a responsabilidade internacional por atividades perigosas ao meio ambiente (SOARES, 2001).

A Convenção de Lugano tem por objetivo garantir uma indenização justa pelos danos ambientais resultantes de atividades perigosas, sendo previsto também meios de prevenção. Esta Convenção constata que a emissão de resíduos ou rejeitos em um Estado pode causar danos em outro Estado, o que torna internacional a questão da reparação adequada.

Para a Convenção, atividade perigosa é a produção, a manipulação, o depósito, a utilização ou o rejeito de uma substância perigosa. No mesmo sentido, há dispositivo normativo que prevê ser perigosa a exploração de uma instalação de incineração, tratamento, manipulação ou reciclagem de resíduos, caso as quantidades envolvidas apresentem um risco significativo para o homem, o meio ambiente ou a propriedade. Dessa forma, as barragens de rejeito de mineração devem ser tratadas como um exemplo de atividade perigosa, nos termos do artigo 2 da Convenção de Lugano.

Assim, aqueles que exploram uma atividade perigosa são responsáveis pelos danos causados. A pessoa que controla a atividade perigosa torna-se responsável pelo dano causado pelas atividades realizadas no período em que se encontrava na gestão das instalações, independente de culpa. Trata-se de consagração internacional da

\footnotetext{
${ }^{5}$ Quebec. Loi sur la Qualité de l’Environnement - LQE. Disponível em: <http://legisquebec.gouv.qc.ca/fr/showDoc/cs/Q-
} 
responsabilidade objetiva por dano. Caso haja uma série de ocorrências com a mesma origem, os operadores, ao tempo de quaisquer dessas ocorrências, serão solidariamente responsáveis.

Em relação às barragens de rejeito da mineração, a Convenção de Lugano determina ser responsável pelos danos causados por rejeitos depositados em local de estocagem permanente o operador do sítio no momento em que aconteceram os danos. Caso os danos sejam percebidos após o fechamento do local de depósito, mas tenham acontecido por conta do depósito anterior de rejeitos, o último operador torna-se responsável.

Ademais, o operador nunca é responsável por danos causados por fenômeno natural de caráter excepcional, inevitável ou irresistível. Da mesma forma, não há responsabilidade do operador se o dano for resultado de obediência de ordem específica ou medida compulsória de autoridade pública ou tenha sido causado por uma atividade perigosa legalmente exercida no interesse da vítima, sendo assim razoável a exposição ao risco. Em matéria de razoabilidade, não há responsabilidade do operador quando o dano tenha sido causado por níveis toleráveis de poluição (SOARES, 2001).

\section{Alemanha}

Não há previsa o expressa na Constituiçã o da Alemanha de um direito ao meio ambiente. A proteção ambiental vem sendo interpretada por meio dos direitos fundamentais, como o direito à vida, à integridade física a e a garantia constitucional da propriedade. Na Alemanha, "o Estado é obrigado a proteger o ambiente através de uma política ativa do ambiente de acordo com a qual a omissão poderia pôr em risco a vida, a saúde e a propriedade do cidadão". Porém, a "obrigação constitucional é bastante vaga e sujeita a concretização por lei ou regulamento" (KRELL, 1997, p. 25).

O dano ambiental na Alemanha somente é reparável quando afetar pessoas identificáveis e o seu patrimônio. Trata-se de uma visão privatística do bem ambiental. O dano só será reparado se a vítima individual lesada ajuizar uma ação de ressarcimento. Assim, a responsabilidade civil na Alemanha é subjetiva, a reparação depende de conduta intencional e de dano considerado "inaceitável" para as condições locais.

A Lei Federal de Responsabilidade Civil Ambiental, teve o objetivo de melhorar a situação jurídica das vítimas de danos individuais devidos à poluição ambiental. Essa lei introduziu a responsabilidade objetiva, baseada na teoria do risco criado, mas apenas em relação a determinadas fontes poluidoras, sobretudo instalações industriais. 
Releva notar que a lei estabeleceu uma presunção de causalidade entre determinadas atividades poluidoras e os danos ambientais, ao lado de outras medidas para compensar as dificuldades de determinação dos responsáveis, como o direito de informação dos indivíduos afetados perante os donos das instalações poluidoras e os órgãos públicos.

Todavia, o Art. $6^{\circ}$ da referida lei, estabelece que não se aplica a presunção de causalidade "se a instalação for apta a, dadas as circunstâncias do evento, causar os danos verificados, presume-se tê-los causado, mas tal presunção não se verifica quando a instalação funcionar dentro das normas ". Ou seja, as externalidades negativas da sociedade de risco são excludentes de responsabilidade na Alemanha, ao contrário do Brasil. Neste caso, resta aos afetados comprovarem o nexo causal entre a atividade e o dano.

Outro ponto relevante é que os particulares não podem exigir o embargo de obras ou atividades legalmente licenciadas, embora possam, em alguns casos, pleitear o pagamento de indenização por danos sofridos em seus direitos individuais. Todavia, há hipóteses em que a existência de autorização administrativa para o exercício da atividade causadora do dano inviabiliza até mesmo esse tipo de pretensão.

Finalmente, segundo Andreas Krell, embora se tenha construído na Alemanha um sistema administrativo relativamente eficiente de proteção aos recursos naturais, a prevenção ou indenização de um dano ambiental, no âmbito do processo civil alemão, somente podem ser reivindicadas como dano individual, que atinge o direito subjetivo de uma pessoa física ou jurídica. No sistema germânico, portanto, o meio ambiente por si, enquanto bem de interesse difuso, ainda não é proteção jurídica (KRELL, 1997, p. 25).

\section{$\underline{\text { Itália }}$}

O Ato único Europeu de 1986, Art. 130 Re 130 T, acolhido na Itália com a Lei 909/86, introduziu três princípios relativos ao ambiente: o princípio da prevenção, o do poluidor- pagador e o princípio de uma proteção jurídica, igual àquela comunitária ou mais rigorosa. Daí o surgimento das agências de controle ambiental na Itália.

\section{O ambiente}

Artigo $130^{\circ}$-R-1- A ação da Comunidade em matéria de ambiente tem por objetivo: Preservar, proteger e melhorar a qualidade do ambiente; contribuir para a proteção da saúde das pessoas; assegurar uma utilização prudente e racional dos recursos naturais.

2 - A ação da Comunidade em matéria de ambiente fundamenta-se nos princípios da ação preventiva, da reparação, prioritariamente na fonte, dos danos ao ambiente e no princípio do poluidor-pagador. As exigências em matéria de proteção do ambiente são uma componente das outras políticas da Comunidade.

3 - Na elaboração da sua ação em matéria de ambiente a Comunidade terá em conta: Os dados científicos e técnicos disponíveis;

as condições do ambiente nas diversas regiões da Comunidade; as vantagens e os encargos que podem resultar da ação ou da ausência de ação; o desenvolvimento econômico e social da Comunidade no seu conjunto e o desenvolvimento equilibrado das suas regiões.

4 - A Comunidade intervirá em matéria de ambiente na medida em que os objetivos 
referidos no no 1 possam ser melhor realizados a nível comunitário do que no nível dos Estados membros considerados isoladamente. Sem prejuízo de certas medidas de caráter comunitário, os Estados membros assegurarão o financiamento e a execução das outras medidas.

5 - A Comunidade e os Estados membros cooperarão, no âmbito das suas respectivas competências, com os países terceiros e as organizações internacionais competentes. As modalidades da cooperação da Comunidade podem ser objeto de acordos entre esta e as partes terceiras interessadas, que serão negociados e celebrados nos termos do artigo 2280 .

O parágrafo anterior não prejudica a competência dos Estados membros para nego- ciarem nas instâncias internacionais e para concluírem acordos internacionais. Artigo 130o-T. As medidas de proteção adaptadas em comum nos termos do artigo $130 \mathrm{o}-\mathrm{S}$ não constituem obstáculo à manutenção e ao estabelecimento por cada Estado membro de medidas de proteção reforçadas compatíveis com o presente Tratado.

Com a Lei n. 349/86, que instituiu o Ministério do Ambiente e as normas em matéria de dano ambiental, o ordenamento jurídico italiano teve a primeira e mais importante disposição em matéria ambiental.

Com a entrada em vigor desta lei, em especial do art. 18, que "determinou o ressarcimento do dano ambiental independentemente da violação dos outros direitos individuais à propriedade privada ou à saúde: com tal norma não se quer mais tutelar o ambiente salubre, mas o ambiente" marcou um passo adiante nos problemas insolúveis em questão ambiental.

Vê-se, assim, que prevalece em matéria ambiental o regime da responsabilidade subjetiva, em que deve necessariamente comparecer a culpa do agente causador do dano. Demais disso, a referência à necessidade de violação de norma legal ou regulamentar parece excluir a responsabilidade do agente nos casos em que sua conduta ou atividade desenvolvam-se de maneira formalmente lícita.

A Lei n. 349/86 define ainda o ato culposo como aquele devido à inobservância das leis, regulamentos, ordens e disciplinas. Também estabeleceu que nos casos de concurso de pessoas no mesmo evento danoso cada qual responde nos limites da própria responsabilidade individual.

Com o advento da Diretiva 2004/35 do Parlamento Europeu e do Conselho, de 21 de abril de 2004, que estabelece diretrizes sobre a responsabilidade ambiental em termos de prevenção e reparação de danos ambientais, incorporada ao direito italiano com a Lei 308 de 15 de dezembro de 2004, o sistema de responsabilização muda sensivelmente.

Segundo Gianluca Limardi (2011, p. 1), esta diretiva introduziu um princípio importante para o direito europeu e internacional, o princípio do 'poluidor pagador', cuja responsabilidade primária na prevenção e reparação do dano seria do operador econômico que criou o perigo ou o próprio dano ${ }^{6}$.

A definição de "operador econômico" no direito italiano está inserta no Artigo 2ª, inciso 6, do Decreto Legislativo 152/2006: 
Dispõe que é "operador", qualquer pessoa singular ou coletiva, pública ou priva- da, que exerce ou controla atividade profissional ou, quando a legislação nacional o preveja, the foi delegado o poder econômico determinante sobre o funcionamento técnico dessa atividade, incluindo o detentor de uma licença ou autorização para tal atividade, ou a pessoa que registra ou notifica tal atividade (tradução nossa) ${ }^{7}$.

Para Limardi (2011, p. 1), o critério de atribuição da responsabilidade por danos ambientais que estão na base das atividades ocupacionais enumeradas no anexo III da Diretiva é do tipo objetivo, considerando a existência de um nexo de causalidade entre a atividade do agente e a ocorrência de danos ambientais. Ao contrário, no caso de danos causados por uma atividade não incluída no anexo III, a atribuição de responsabilidades deve ser baseada na demonstração de dolo ou culpa do agente econômico, sendo, portanto subjetiva.

Ainda segundo Limardi (2011, p. 1), isso significa que o princípio geral de atribuição do poluidorpagador não pode ser aplicado automaticamente, mas será integrado com a avaliação da análise da culpa. Portanto permanece um princípio de responsabilidade objetiva, embora sofra exceções significativas como, por exemplo, o fato de a Diretiva não se aplicar a casos de danos

Haverá também responsabilidade civil por danos ambientais no Direito italiano, acatando o Art. 311 da Diretiva, quando a realização de qualquer ato ilegal, omitindo atividades ou comportamentos, com violação da lei, regulamento ou disposições administrativas, com negligencia, incompetência ou violação das regras técnicas, causar danos ao meio ambiente, alterando-o, deteriorando-o ou destruindo-o, no todo ou em parte, o causador do dano é obrigado a restaurar à situação anterior ou, na sua falta, compensar com ativos equivalentes ao Estado.

Pode-se observar que, no Direito italiano, se estiverem dentre as atribuições do operador - tanto empresas, como as agências de proteção ambiental e as autoridades federais, regionais e municipais - exercer ou fiscalizar as atividades inclusas no anexo III da Diretiva 2004/35 CE, responde objetivamente pelos danos causados ao meio ambiente, podendo invocar excludentes de responsabilidade.

Por outro lado, se a atividade exercida ou sujeita a controle estiver fora das listadas no anexo III, o operador responde subjetivamente, caso seja provada culpa ou dolo.

A Itália também já admite a responsabilidade solidária decorrente da Diretiva 2004/35, mas dentro dos limites da participação de cada um no dano. Esta prevê que o operador não pode ser responsabilizado se ele não

\footnotetext{
${ }^{6} \mathrm{La}$ direttiva in esame ha introdotto un principio importante per il diritto comunitario e internazionale, il principio "chi inquina paga”, secondo il quale la responsabilità primaria, relativa alla prevenzione e riparazione del danno spetterebbe all'operatore economico che ha creato la situazione di pericolo o il danno stesso.

${ }^{7}$ Per la definizione di "operatore economico" si rinvia al testo di cui all'art. 2, $6^{\circ}$ comma, D.lgs. 152/2006 il quale prevede che è "operatore": qualsiasi persona fisica o giuridica, sia essa pubblica o privata, che esercita o controlla, un'attività professionale oppure, quando la legislazione nazionale lo preveda, a cui è stato delegato un potere economico decisivo sul funzionamento tecnico di tale attività, compresi il titolare del permesso o dell'autorizzazione a svolgere detta attività o la persona che regis- tra o notifica l'attività medesima”.
} 
tiver culpa ou comportamento negligente. Ou seja, para que haja solidariedade, deve ser demonstrada culpa ou dolo e ser feita a aferição da participação de cada um na ocorrência do dano.

Como se pode observar, a responsabilização ambiental na Itália adota a Diretiva 2004/35 como norteadora, sendo, em regra, subjetiva, ficando limitada a responsabilidade objetiva àquelas atividades especificadas no Anexo III, devendo ser comprovado o nexo de causalidade entre a ação e o dano.

A despeito da falta de rigor legislativo na questão da responsabilidade civil ambiental no Direito italiano em comparação com o Direito brasileiro, seu sistema de prevenção, inteiramente ligado às agências de controle ambiental, é bastante eficaz, contendo normas, regulamentos e limites que impedem a ação predatória do ambiente.

\section{França}

No Direito francês não existem normas específicas sobre responsabilidade civil em matéria ambiental, a reparação do dano ambiental pode ser fundamentada no regime clássico do Código Civil, de responsabilidade subjetiva, ou na teoria da responsabilidade pelo fato da coisa, também prevista no Código Civil, mas de natureza objetiva.

Assim, o direito francês, instituiu nitidamente um princípio geral da responsabilidade civil, abandonando o critério de enumerar os casos de composição obrigatória. Além disso, estabeleceu certos princípios, que exerceram sensível influência nos outros povos: direito à reparação sempre que houvesse culpa, ainda que leve, separando-se a responsabilidade civil (perante a vítima) da responsabilidade penal (perante o Estado); a existência de uma culpa contratual (a das pessoas que descumprem as obrigações) e que não se liga nem a crime nem a delito, mas se origina da negligencia ou da imprudência.

Era a generalização do princípio aquiliano: in lege Aquilia et levíssima culpa venir ou seja, o de que a culpa, ainda que levíssima, obriga a indenizar (MAZEAUD; MAZEAUD, 2013, p. 48).

A noção de culpa in abstrato e a distinção entre culpa delitual e culpa contratual foram inseridas no Código Napoleão, inspirando a redação dos artigos 1.382 e 1.383. A responsabilidade civil se funda na culpa - foi a definição que partiu daí para inserir-se na legislação de todo o mundo (DIAS, 1997, p. 20). Daí por diante observou-se a extraordinária tarefa dos tribunais franceses, atualizando os textos e estabelecendo uma jurisprudência digna dos maiores encômios.

Outro ponto a ser salientado, é o recurso à teoria dos direitos de vizinhança, mas que depende da demonstração de que os incômodos e a poluição causados pelo vizinho excedem os padrões aceitáveis para aquele determinado local e momento, ou seja, trata-se de solução casuística. Há ainda algumas normas esparsas que preveem regimes específicos de reparação para determinados danos, com fundamento na teoria do risco 
criado. É o caso da responsabilidade por danos nucleares e dos danos causados por aeronaves (SAMPAIO, 1998, p. 167).

\section{Na América Latina}

\section{$\underline{\text { Argentina }}$}

No Direito argentino, após a reforma constitucional de 1994, foi positivada a preocupação com o meio ambiente, especificamente no Art. 41, previsto no Capítulo II - "Novos Direitos e Garantias", que prevê a necessidade de um desenvolvimento sustentável para a preservação das gerações presentes e futuras:

Todos os habitantes têm direito a um meio ambiente saudável e equilibrado, adequa- do para o desenvolvimento humano e para que as atividades produtivas satisfaçam as necessidades presentes sem comprometer as das gerações futuras; e têm o dever de preservá$10^{8}$.

No que concerne ao dano ambiental, cumpre destacar a previsão legal, ainda no artigo mencionado, sobre a obrigação de recompor: "O dano ambiental gerará prioritariamente a obrigação de reparar, conforme estabelecido por lei".

Posteriormente, esse instituto foi regulamentado pela Lei n. 25.675/2002, denominada Ley General Del Ambiente, aplicável no caso de dano ambiental coletivo, que preceitua em seu Art. 28:

Aquele que causar o dano ambiental será objetivamente responsável por sua restauração para o estado anterior a sua produção. Se não for tecnicamente viável, será determinada pelos tribunais a indenização substitutiva, que deverá ser depositada no Fundo de Compensação Ambiental criado por essa Lei, a ser administrado pela autoridade de execução, sem prejuízo de outras ações legais que puderem corresponder?.

Barroso entende que no Direito argentino "a doutrina e a jurisprudência deram efetividade à responsabilidade objetiva por dano ambiental (resultado de uma interpretação ampliativa, bem como da integração de alguns dispositivos do Código Civil) [...]”. Assevera que esta regra ainda vigora nos casos de dano ambiental individual - às pessoas ou a seu patrimônio - e conclui (2006, p. 91):

Com isso, o Direito Argentino apresenta dois regimes de responsabilidade civil por danos ambientais. O primeiro, proveniente do Direito comum, a regular os danos ambientais individuais (aplicando-se basicamente as regras atinentes ao Código Civil); o segundo, advindo do Direito Ambiental, disciplina os danos ambientais à coletividade (coincidência das normas da Ley General de Ambiente). Portanto, vê^-se, ainda, claramente que seu

\footnotetext{
${ }^{8}$ Todos los habitantes gozan del derecho a un ambiente sano, equilibrado, apto para el desarrollo humano y para que las actividades productivas satisfagan las necesidades presentes sin comprometer las de las generaciones futuras; $y$ tienen el deber de preservarlo. ARGENTINA. Constituiça o Nacional.

${ }^{9}$ El que cause el dan o ambiental será objetivamente responsable de su restablecimiento al estado anterior a su producción. En caso de que no sea técnicamente factible, la indemnización sustitutiva que determine la justicia ordinária interviniente, deberá depositarse en el Fondo de Compensación Ambiental que se crea por la presente, el cual será administrado por la autoridad de aplicación, sin perjuicio de otras acciones judiciales que pudieran corresponder. ARGENTINA. Ley Nacional 25.675. Ley General del Ambiente.
} 
sistema jurídico também distingue o dano ambiental privado do dano ambiental coletivo.

Cumpre ressaltar que em ambos os sistemas é notória a prevalência da recomposição do status quo ante, fazendo com que somente no caso de impossibilidade seja determinada a reparação em dinheiro, conforme se verifica no Art. 41 da Constituição Nacional, Art. 1.083 do Código Civil argentino e Art. 28 da Ley n. $25.675 / 2002$.

Patrícia Faga Iglecias Lemos (2008, p. 95) aduz que nos casos em que houver "interesses difusos ou coletivos, a indenização deve reverter para retribuir de alguma forma a comunidade atingida, ou, se não é possível a compensação dessa maneira, deve haver reversão para um fundo de garantia para os casos de demandados insolventes".

Outra característica da legislação argentina é a previsão de responsabilidade solidária. O Art. 31 da Lei n. 25.675/2002 aduz que, se na prática do dano ambiental coletivo participarem duas ou mais pessoas, ou não for possível a determinação exata da extensão do dano atribuído a cada responsável, todos serão solidariamente responsáveis pela reparação perante a sociedade, sem prejuízo, nesse caso, do direito de repetição para que o juiz interveniente poderá determinar o grau de responsabilidade de cada pessoa responsável ${ }^{10}$.

\section{A RESPONSABILIDADE CIVIL AMBIENTAL NO DIREITO BRASILEIRO}

Partindo-se da sucinta distinção entre as teorias subjetivas e objetiva, podemos agora analisar quais delas são adotadas pelo direito ambiental.

No Direito brasileiro, a responsabilidade civil era unicamente subjetiva, entretanto, havia grande dificuldade em se provar a culpa do causador do dano ambiental. Para gerar o dever de indenizar, fazia-se necessária a existência de quatro elementos, quais sejam: 1) ação ou omissão; 2) dano; 3) nexo causal; e 4) culpa ou dolo. Baseava-se na ideia da culpa em sentido estrito (negligencia, imperícia e imprudência) e do dolo, fundamentados no Art. 159 do Código Civil de 1916: "Aquele que, por ação ou omissão voluntária, negligencia, ou imprudência, violar direito, ou causar prejuízo a outrem, fica obrigado a reparar o dano”. Luís Paulo Sirvinskas afirma que “a culpa tinha por escopo a violação de um dever jurídico, legal ou contratual” (SIRVINSKAS, 2006, p. 153).

O civilista Caio Mário da Silva Pereira assim observa que a "teoria da responsabilidade subjetiva erige em pressuposto da obrigação de indenizar, ou de reparar o dano, o comportamento culposo do agente, ou

\footnotetext{
${ }^{10}$ Si en la comisión del dan o ambiental colectivo, hubieren participado dos o más personas, o no fuere posible la determinación precisa de la medida del dan o aportado por cada responsable, todos serán responsables solidariamente de la reparación frente a la sociedad, sin perjuicio, en su caso, del derecho de repetición entre sí para lo que el juez interviniente podrá determinar el grado de responsabilidad de cada persona responsable
} 
simplesmente a culpa, abrangendo no seu contexto a culpa propriamente dita e o dolo do agente" (PEREIRA, 1990, p. 35).

O Código Civil de 2002 dispõe, no caput do Art. 927, que "Aquele que, por ato ilícito (Artigos 186 e 187), causar dano a outrem, fica obrigado a repará-lo”. E estabeleceu o conceito de ato ilícito nos Artigos. 186 e 187, respectivamente: "Aquele que, por ação ou omissão voluntária, negligência ou imprudência, violar direito e causar dano a outrem, ainda que exclusiva- mente moral, comete ato ilícito" e "também comete ato ilícito o titular de um direito que, ao exercê-lo, excede manifestamente os limites impostos, pelo seu fim econômico ou social, pela boa fé ou pelos bons costumes". Dessa forma, resta notório que, pelos artigos acima citados, do Código Civil em vigor, também prevalece a teoria subjetiva; para que o agente causador do dano seja responsabilizado, faz-se necessária a comprovação da negligência, imprudência ou imperícia, além do dano e do nexo causal.

Todavia, no Direito Ambiental, sempre houve uma enorme dificuldade em demonstrar a culpa do agente causador do dano pela teoria subjetiva. Dessa forma, devido à importância do bem tutelado, a doutrina passou a adotar a teoria objetiva, responsabilizando o agente causador do dano independentemente de ter agido com culpa, conforme análise a seguir.

Paulo de Bessa Antunes (2010. p. 211) assegura que "a responsabilidade por danos causados ao meio ambiente, no sistema jurídico brasileiro, é matéria que goza de status constitucional, visto que inserida no capítulo voltado para a proteção do meio ambiente".

Em contrapartida, Fábio Ulhoa Coelho (2009, p. 381) não compartilha deste pensamento, ao afirmar que:

O preceito constitucional em foco cuida das atividades consideradas lesivas ao meio ambiente passíveis de sanção penal e administrativa, e, portanto, de atos ilícitos. Trata-se de responsabilidade aquiliana. No Brasil, assim, a responsabilidade do poluidor é objetiva por força de lei ordinária em vigor desde 1981.

Dessa forma, não há, pela leitura do dispositivo constitucional, nenhuma incompatibilidade com a Lei infraconstitucional (Lei n. 6.938/81). Essa teoria já está consagrada na doutrina e na jurisprudência. Adotou-se a teoria do risco integral. Assim, em conformidade com o $\$ 3^{\circ}$ do Art. 225 da Constituição da República Federativa do Brasil, é notória a existência de uma tríplice responsabilização aos agentes dos danos ambientais, qual seja, no âmbito penal, administrativo e civil, uma vez que assim estabelece:

"As condutas e atividades consideradas lesivas ao meio ambiente sujeitarão os infratores, pessoas físicas ou jurídicas, a sanções penais e administrativas, independentemente da obrigação de reparar os danos causados".

A partir desse dispositivo, é possível verificar que no texto constitucional não foi especificado o regime de responsabilidade adotado no país. Todavia, a Lei de Política Nacional do Meio Ambiente, no 6.938, de 31 de agosto de 1981, no $\$ 1^{\circ}$ de seu Art. 14, dispõe acerca do regime objetivo:

Sem obstar a aplicação das penalidades previstas neste artigo, é o poluidor obrigado, 
independentemente da existência de culpa, a indenizar ou reparar os danos causados ao meio ambiente e a terceiros, afetados por sua atividade. O Ministério Público da União e dos Estados terá legitimidade para propor ação de responsabilidade civil e criminal, por danos causados ao meio ambiente.

A teoria objetiva prescinde de demonstração de culpa, bastando a comprovação do dano e do nexo causal, tendo sido assim definida por Caio Mário Pereira (1990, p. 35):

A doutrina objetiva, ao invés de exigir que a responsabilidade civil seja resultante dos elementos tradicionais (culpa, dano, vínculo de causalidade entre uma e outro) assenta na equação binária cujos polos são o dano e a autoria do evento danoso. Sem cogitar da imputabilidade ou de investigar a antijuridicidade do fato danoso, o que importa para assegurar o ressarcimento é a verificação se ocorreu o evento e se dele emanou prejuízo. Em tal ocorrendo, o autor do fato causador do dano é o responsável.

No Brasil, Caio Mário da Silva Pereira (1990, p. 35) foi ferrenho defensor da responsabilidade objetiva.

Para ele, o impulso desenvolvimentista levou a uma multiplicação das oportunidades e das causas de danos, ficando o lesado, muitas vezes, sem conseguir provar a culpa e sem a reparação do dano sofrido.

Assim, a responsabilidade objetiva foi surgindo aos poucos na doutrina e jurisprudência, sendo adotada paulatinamente em leis esparsas até os dias atuais. Apesar da responsabilidade subjetiva ser a regra, determinadas matérias elencadas na Constituição Federal, no Código Civil e na legislação brasileira tratam da responsabilidade sem culpa, sendo necessário apenas que se configure a ação ou omissão, o nexo de causalidade e o dano, como é o caso do Direito Ambiental.

Nesse mesmo entendimento, o parágrafo único do Art. 927, do Código Civil de 2002, prevê^: "Haverá obrigação de reparar o dano, independentemente de culpa, nos casos especificados em lei, ou quando a atividade normalmente desenvolvida pelo autor do dano implicar, por sua natureza, risco para os direitos de outrem".

Maria Helena Diniz (2009, p. 391), defende a aplicação da Teoria da Responsabilidade Objetiva no caso dano ambiental, sustentando que a "responsabilidade civil por dano ao meio ambiente é objetiva, bastando a comprovação do nexo de causalidade entre o ato do lesante e o dano provocado ao meio ambiente natural e cultural, sendo irrelevante a aferição de culpa do poluidor ou da ilicitude de seu ato".

Dessa forma, não restam dúvidas acerca da obrigação que o agente responsável pelos prejuízos possui de reparar o dano causado. Assim, a reparação por meio de uma indenização tem o intuito de fazer com que o meio ambiente lesado retorne ao status quo ante, ou seja, ao estado em que se encontrava antes da ocorrência do dano.

\section{Requisitos da Responsabilidade Civil Ambiental}

No regime da responsabilidade objetiva, fundada na teoria do risco da atividade, para que se possa pleitear a reparação do dano ambiental, basta a demonstração da ação lesiva, do dano e do nexo de causalidade com a fonte poluidora ou degradadora. 


\section{Ação ou omissão: sujeito responsável}

Segundo o ordenamento jurídico e a legislação vigente o principal responsável pelo dano causado ao meio ambiente é o poluidor. A lei 6.938/1981 em seu artigo 3, inciso IV, define poluidor como "a pessoa física ou jurídica, de direito público ou privado, responsável, direta ou indiretamente, por atividade causadora de degradação ambiental”. Pela definição de poluidor estabelecida na lei, observa-se que a responsabilidade por danos ao meio ambiente é muito abrangente, tendo em vista que, podem ser responsáveis tanto as pessoas físicas quanto as pessoas jurídicas.

Sendo assim, aquele que causou uma degradação, modificação ou alteração no meio ambiente deve por este ato responder, seja uma pessoa física ou jurídica, tendo em vista que é dever de todos tanto do Poder Público como do particular a preservação do meio ambiente.

Ao adotar a responsabilidade civil objetiva relacionada à teoria do risco integral faz-se necessário lembrar do instituto jurídico da solidariedade, visto que, a responsabilidade por dano ambiental além de objetiva é solidária.

Neste mesmo sentido, José Alfredo Baracho Júnior (2000, p. 307) menciona que:

[...] Grande parte da doutrina brasileira tem firmado a opinião de que a responsabilidade civil por dano ao meio ambiente fundamenta-se na teoria do risco, sendo uma responsabilidade solidária e de caráter objetivo.

Logo, caso haja mais de um responsável pelo dano causado ao meio ambiente, ou seja, existindo uma pluralidade de agentes responsáveis, todos deverão responder solidariamente pelo prejuízo causado nos moldes do artigo 942 do Código Civil ao dispor que "[...] se a ofensa tiver mais de um autor, todos responderão solidariamente pela reparação".

Na mesma linha de raciocínio Paulo Affonso Leme Machado (2006, p. 343-344) ilustra que:

Num distrito industrial ou num conglomerado de indústrias pode ser difícil apontarem-se todas as fontes poluidoras que tenham causado prejuízo. A vítima não está obrigada a processar conjuntamente todos os poluidores, podendo escolher aquele que the convier, chamar à responsabilidade, por exemplo, optando por um poluidor solvente e não pelo insolvente.

Desse modo, constata-se que a responsabilidade civil ambiental é solidária podendo um ou todos os agentes causadores de um dano ambiental responderem integralmente pela reparação do dano, cabendo aquele que reparar o dano sozinho a ação de regresso contra os demais coobrigados.

\section{Dano ambiental}

A reparação do dano ambiental, salienta Villaça Azevedo (1994, p. 256), só é devida quando existe "o dano e nem todo dano se indeniza". Logo, é de suma importância caracterizar, na perspectiva da proteção do meio 
ambiente, o que venha a ser dano? Álvaro Valery Mirra (2003, p. 89) traz um conceito bastante aprofundado, segundo o qual o dano ambiental consiste em toda degradação do meio ambiente, incluindo os aspectos naturais, culturais e artificiais que permitem e condicionam a vida, visto como bem unitário imaterial coletivo e indivisível, e dos bens ambientais e seus elementos corpóreos e incorpóreos específicos que o compõem, caracterizadora da violação do direito difuso e fundamental de todos à sadia qualidade de vida em um ambiente ecologicamente equilibrado.

O evento danoso, como visto, vem a ser a resultante de atividades que, de maneira direta ou indireta, causem a degradação da qualidade do meio ambiente ou de um ou mais de seus componentes (MILARÉ, 2011, p. 1253).

Milaré (2011, p. 1255) ainda completa que em se tratando de dano ambiental a determinação do nexo causal é uma tarefa mais complexa e difícil porque as consequência da poluição, ainda perduram por muito tempo na natureza, seja pela diversidade de causas, das fontes e de comportamentos, seja pela sua tardia consumação e constatação, seja pelas dificuldades técnicas e financeiras de sua apuração, seja "pela longa distância entre a fonte emissora e o resultado lesivo", seja pelas sequelas causadas ao meio ambiente que muitas vezes só aparecerão depois de muito tempo, por vezes, até irreversíveis.

\section{$\underline{\text { Nexo de causalidade }}$}

Não obstante a dificuldade de recomposição do dano, há no Direito brasileiro, mecanismos de ressarcimento do dano ambiental patrimonial, quais sejam, retorno ao estado anterior à lesão e indenização pecuniária.

A doutrina, no pensamento de Steigleder (2011, p. 171), considera que o nexo causal, embora tendo como ponto de partida as leis naturais sem as quais o dano não ocorreria, é submetido também a critérios normativos, que traduzem opções valorativas para sua aferição: "a identificação da causa de um dano implica juízos de valor, informados pelo Direito, em que se fazem escolhas, fundadas em critérios tais como adequação social, periculosidade da atividade, proximidade temporal entre ação e a omissão e o dano, probabilidade, etc.".

Rui Stoco (2007, p. 154-179), a referir-se ao nexo causal, adverte:

[...] ser este o mais delicado dos elementos da responsabilidade civil e o mais difícil de ser determinado. Aliás, sempre que um problema jurídico vai ter na indagação ou na pesquisa da causa, desponta a sua complexidade maior. Mesmo que haja culpa e dano, não existe obrigação de indenizar se entre ambos não se estabelecer a relação causal.

Muitas teorias vão tentar explicar as causas de um dano. A Teoria da Causalidade Adequada, por exemplo, busca aferir, entre as diversas causas, aquela que apresente idoneidade lesiva para a produção do dano. A 
avaliação dessa idoneidade é realizada por um juízo de adequação social que, abstratamente, considera que suposta causa (condição) tem aptidão para produzir o dano.

Já a Teoria da Equivalência das Condições sustenta que o liame causal ocorre sempre que a condição houver concorrido para o dano, mesmo que não seja a causa direta deste. Nesse sentido, segundo Steigleder (2011, p. 278), "a grande problemática envolvendo o nexo de causalidade na área ambiental é que o dano ambiental pode ser resultado de várias causas, concorrentes, simultâneas ou sucessivas, dificilmente tendo uma única e linear fonte”.

Daí que, aferir o nexo de causalidade a partir de juízos de "adequação social", em que várias causas concorrem para o dano, pode levar a situações de não responsabilização, como nos casos de tufões, enchentes, tempestades, aumento do nível dos oceanos, favorecendo o degradador, que passa a invocar culpa de terceiros ou da vítima, caso fortuito ou força maior para exonerar-se do dever de indenizar, em prejuízo ao princípio basilar do Direito Ambiental, que é o da precaução.

Tais dificuldades na aferição do nexo causal têm reforçado as teses doutrinárias e jurisprudenciais adeptas à Teoria do Risco Integral, como veremos adiante.

Parte da doutrina e dos tribunais, porém, adota a Teoria do Risco Criado, cujo diferencial é admitir as excludentes de responsabilidade civil - culpa exclusiva da vítima, fato de terceiros e caso fortuito ou força maior. Tal teoria é alinhada à Teoria da Causalidade Adequada e tem como elemento central o perigo, devendo-se aferir se há liame causal entre a ação ou omissão e o dano. Entendimento defendido por Toshio Mukai, Von Adamek, Andreas Joachim Krell, Helita Barreiro Custódio, Fernando Noronha, dentre outros.

Assim, no sistema de responsabilização do dano ambiental no Direito brasileiro, doutrina e jurisprudência adotam a teoria objetiva sob duas vertentes: 1) as que admitem excludentes de responsabilidade (Teoria do Risco Administrativo, do Risco Criado, do Risco-Proveito, do Risco Atividade) e, 2) as que não admitem excludentes (Teoria do Risco Integral).

\section{Responsabilidades por danos decorrentes de rompimento de barragem}

A atividade de mineração possui interface direta com a realidade do meio ambiente, visto que o processo de extração do mineral causa graves danos ao meio ambiente. Tal atividade, constitui, sem dúvida, uma agressão ao meio ambiente, visto que o processo de purificação do minério gera uma grande quantidade de rejeitos. Estes, por sua vez, necessitam de uma acomodação, sendo que, o método mais comumente utilizado para disposição dos rejeitos são as barragens.

Entretanto, como verificamos no decorrer deste trabalho, as barragens de rejeitos podem causar grandes danos ambientais, se não forem adequadamente planejadas, operadas e mantidas. A importância do tema é de tal 
ordem que o legislador impôs ao minerador a responsabilidade de "recuperar o meio ambiente degradado", conforme dispõe o artigo $225, \$ 2^{\circ}$, da Constituição Federal ${ }^{11}$. Vale ressaltar que, anteriormente, a Lei 6.938/1981, em seu artigo 2º, VIII ${ }^{12}$, já se referia à "recuperação de áreas degradadas" como um dos princípios programáticos informadores da Política Nacional do Meio Ambiente.

Além disso, o artigo $14^{\circ} \$ 1^{\circ}$ da Lei da Política Nacional do Meio Ambiente (lei no 6.938/81), prevê que o poluidor é obrigado, independentemente da existência de culpa, a indenizar ou reparar os danos causados ao meio ambiente e a terceiros, afetados por sua atividade ${ }^{13}$.

Ademais, o artigo 927, parágrafo único do Código Civil atribui a responsabilidade civil àqueles que exercem atividades de risco, como por exemplo, a extração de minérios:

Art. 927. Aquele que, por ato ilícito (arts. 186 e 187), causar dano a outrem, fica obrigado a repará-lo.

Parágrafo único. Haverá obrigação de reparar o dano, independentemente de culpa, nos casos especificados em lei, ou quando a atividade normalmente desenvolvida pelo autor do dano implicar, por sua natureza, risco para os direitos de outrem.

O que o legislador quer, portanto, "é que a própria recuperação do dano ecológico produzido pela mineração se faça de acordo com uma decisão técnica, isto é, de acordo com uma solução possível, diante do fato de que a mineração se procede em bens ambientais não renováveis. No caso, é uma recuperação que visa assegurar um determinada uso humano da área degradada. A recuperação do meio ambiente degradado se faz com a implementação de políticas que sejam capazes de dar 'solução técnica', ou seja, que leve em consideração todas as variáveis envolvidas no problema" (ANTUNES, 2000, p. 247).

A recuperação, segundo expresso no Manual de Recuperação de Áreas Degradadas pela Mineracão, do IBAMA, "significa que o sítio degradado sera retornado a uma forma de utilização de acordo com o plano preestabelecido para o uso do solo. Implica em que uma condição estável sera obtida em conformidade com os valores ambientais, estéticos e sociais da circunvizinhança. Significa, também, que o sítio degradado terá condições mínimas de estabelecer um novo equilíbrio dinâmico, desenvolvendo um novo solo e uma nova paisagem"

\footnotetext{
${ }^{11}$ Art. 225. Todos têm direito ao meio ambiente ecologicamente equilibrado, bem de uso comum do povo e essencial à sadia qualidade de vida, impondo-se ao Poder Público e à coletividade o dever de defendê-lo e preservá- lo para as presentes e futuras gerações. $\$ 2^{\circ}$ Aquele que explorar recursos minerais fica obrigado a recuperar o meio ambiente degradado, de acordo com solução técnica exigida pelo órgão público competente, na forma da lei. Cf. BRASIL. Constituiçã o da República Federativa do Brasil, de 5 de outubro de 1988 .

${ }^{12}$ Art 2० - A Política Nacional do Meio Ambiente tem por objetivo a preservação, melhoria e recuperação da qualidade ambiental propícia à vida, visando assegurar, no País, condições ao desenvolvimento sócio-econômico, aos interesses da segurança nacional e à proteção da dignidade da vida humana, atendidos os seguintes princípios: VIII - recuperação de áreas degradadas; Cf. BRASIL. Lei n. 6.938, de 31 de agosto de 1981.

${ }^{13}$ Art 14 - Sem prejuízo das penalidades definidas pela legislação federal, estadual e municipal, o não cumprimento das medidas necessárias à preservação ou correção dos inconvenientes e danos causados pela degradação da qualidade ambiental sujeitará os transgressores: $\$ 1^{\circ}$ - Sem obstar a aplicação das penalidades previstas neste artigo, é o poluidor obrigado, independentemente da existência de culpa, a indenizar ou reparar os danos causados ao meio ambiente e a terceiros, afetados por sua atividade. $\mathrm{O}$
} 
(IBAMA, 1990, p.3).

O projeto de recuperação deve contemplar cronologicamente os objetivos a serem alcançados, em escalas de curto, médio e longo prazos. Os objetivos de curto prazo envolvem "recomposição topográfica do terreno; controle de erosão; revegetação do solo; controle dos depósitos de estéreis e rejeitos”, entre outros. A médio prazo, busca-se a "reestruturação das propriedades físicas e químicas do solo; a reciclagem dos nutrientes e o reaparecimento da fauna". E, finalmente, a longo prazo, "a autossustentação do processo de recuperação, o interrelacionamento entre solo-planta-animal, e a utilização future da área" (ALMEIDA, 1999, p.94).

Ademais, a obrigação de recuperar o meio ambiente degradado, não está condionada a apuração de culpa, já que "o constituinte quis reconhecer desde logo que essa atividade, pelo seu simples exercício, provoca degradação ambiental, pelo que, independentemente do regime permissionário de sua exploração, na forma prevista no capítulo da ordem econômica, e sem embargo do cumprimento de todas as normas e padrões fixados no ato administrative que a autorizou, restaria a obrigação de recuperar o meio ambiente. Acatada estaria assim a doutrina objetivo de responsabilidade em toda a sua plenitude" (ATHIAS, 1993, p. 248).

\section{CONSIDERAÇÕES FINAIS}

A processo de extração de minérios possui direta ligação com a realidade do meio ambiente, visto que tal atividade causa graves danos ao meio ambiente. Dessa forma, constitui, sem dúvida, uma agressão ao meio ambiente, visto que o processo de purificação do minério gera uma grande quantidade de rejeitos. Estes, por sua vez, necessitam de uma acomodação, sendo que, o método mais comumente utilizado para disposição dos rejeitos são as barragens.

Entretanto, como verificamos no decorrer deste trabalho, as barragens de rejeitos podem causar grandes danos ambientais, se não forem adequadamente planejadas, operadas e mantidas, como ocorreu no Distrito de Bento Rodrigues, Município de Mariana - MG. Dessa forma, a importância do tema é de tal ordem que o legislador impôs ao explorador de minérios a responsabilidade de recuperar o meio ambiente degradado.

Ademais, a obrigação de recuperar o meio ambiente degradado, não está condicionada a apuração de culpa, já que "o constituinte quis reconhecer desde logo que essa atividade, pelo seu simples exercício, provoca degradação ambiental, pelo que, independentemente do regime permissionário de sua exploração, restaria a obrigação de recuperar o meio ambiente.

Em relação ao Direito Internacional, há uma diversidade de entendimentos e sistemas sobre a responsabilizaça o civil. Dos países aqui estudados, a Alemanha adota a Teoria da Responsabilidade Civil

Ministério Público da União e dos Estados terá legitimidade para propor ação de responsabilidade civil e criminal, por danos 
Subjetiva. A Itália, cuja responsabilizaça o civil era exclusivamente subjetiva, incorporou recentemente a Diretiva 2004/35 do Conselho Europeu e vem adotando, para atividades específicas, a responsabilidade objetiva.

A Argentina apresenta dois regimes de responsabilidade: um subjetivo, que regula os danos ambientais individuais e outro objetivo, que regula os danos coletivos. Já nos Estados Unidos da América a responsabilidade civil por danos ambientais é objetiva, além de ser solidária e retroativa.

Quanto à previsão constitucional, Alemanha, Estados Unidos e Itália não possuem dispositivos específicos para a tutela ambiental, ao contrário do que ocorre com Brasil e Argentina. Apesar disso, a proteção ambiental na Alemanha e Itália vem sendo interpretada por meio dos direitos fundamentais, como o direito à vida, à integridade física e a garantia constitucional da propriedade.

Pela análise dos sistemas de proteção ao meio ambiente realizada no presente trabalho, é possível concluir que o Brasil possui uma legislação bastante moderna, cujo sistema de responsabilização adotado é objetivo, apresentando maior semelhança com o direito norte-americano.

Em contrapartida, o Brasil não tem instrumentos para que seja realizada a reparação do dano imediatamente após sua ocorrência, tal como ocorre nos Estados Unidos e Itália, cujas agências de proteção ambiental entram em ação, independentemente da imputação da responsabilidade ao seu causador. Nesse aspecto, apesar da existência de leis, a reparação do dano, no Brasil, é pouco eficaz, devendo ser criados instrumentos executivos para que haja uma tutela mais efetiva.

Assim, verifica-se que o problema não é apenas jurídico. As diversas normas jurídicas internas e internacionais sobre a proteção ambiental geralmente estabelecem obrigações e responsabilidades bem determinadas. No âmbito internacional, apesar da diversidade de tratados, destaca-se, nas relações entre Estados fundadas em aspectos ambientais, o princípio da prevenção como elemento central das disposições específicas de gestão do território por parte do Estado.

Dessa forma, o titular da soberania territorial deve implementar internamente regras mais restritivas quanto à destinação dos resíduos de mineração. Dentre todas as medidas a serem internalizadas pelos Estados, em cumprimento ao princípio da prevenção, o licenciamento ambiental de barragens de rejeitos da mineração é uma obrigação verificada nos diversos ordenamentos jurídicos nacionais.

De fato, quando do projeto de execução de barragens de rejeito da mineração, os Estados devem agir em favor da prevenção de danos, especialmente em relação àqueles considerados significativos. Para tanto, deve ser realizado o estudo de impacto ambiental, além da transparência na divulgação das informações ambientalmente relevantes, bem como a participação do público na tomada de decisões governamentais. É por meio do 
licenciamento ambiental que se cumpre o princípio da prevenção de danos com barragens de rejeitos de mineração.

Contudo, apesar da prevenção ser uma obrigação internacional erga omnes, apesar dos licenciamentos ambientais estarem universalizados na prática interna dos diferentes Estados, os acidentes com barragens de rejeitos da mineração continuam acontecendo.

O problema é econômico. Há que se instituir um sistema jurídico internacional que obrigue efetivamente os Estados a adotarem medidas que possam garantir a segurança das barragens de rejeitos da mineração sem que considerações de ordem econômica possam prevalecer em detrimento da preservação ambiental. $\mathrm{O}$ grande desafio é implementar tal sistema em uma comunidade internacional marcada pela desigualdade econômica.

No Brasil, verifica-se que, apesar da criação de normas jurídicas que pretendem regulamentar o funcionamento e a segurança das barragens na mineração, como a Lei 12.334/2010, que estabelece a Política Nacional de Segurança de Barragens, acidentes continuam a ocorrer. Por maior que seja a diligência, o zelo e o cumprimento da legislação em vigor pelas empresas mineradoras em relação à segurança de suas barragens, tais medidas vêm se apresentando insuficientes para evitar que acidentes aconteçam.

Dessa forma, medidas preventivas devem ser implementadas imediatamente, sob pena de presenciarmos mais uma ruptura dessas estruturas. Necessária, portanto, a adoção, nas três esferas de poder, de ações mais restritiva em relação à gestão dos rejeitos da atividade minerária, calcadas no princípio da prevenção, alicerce para a adoção de mecanismos tendentes a evitar a concretização de danos socioambientais.

No âmbito da competência do Poder Executivo, cabe à União, aos Estados e aos Municípios, diagnosticar, analisar e propor alterações nas normas que regulamentam a disposição dos resíduos da mineração, com o intuito de aumentar os níveis de segurança das barragens.

Entretanto, vale lembrar que, de nada valerá o aperfeiçoamento das normas de segurança de barragens se a fiscalização por parte dos órgãos ambientais se mantiver fragilizada. Necessário reforçar, tanto com equipamentos quanto com material humano, as estruturas administrativas responsáveis pela aplicação do poder de polícia ambiental em todos os entes federados, sob pena de se tornarem inaplicáveis as normas preventivas instauradas.

Já na esfera Legislativa, deve-se instituir incentivos fiscais, financeiros, ou creditícios às indústrias e entidades dedicadas à reutilização, ao tratamento e à reciclagem de resíduos sólidos produzidos no território nacional, além de fomentar a pesquisa e a implantação de modelos de disposição de resíduos que possam vir a substituir as barragens de rejeitos de mineração. 
Além disso, seria interessante a análise, pelo Poder Legislativo, da utilização do mecanismo da extrafiscalidade com o objetivo de direcionar comportamentos no setor minerário, incentivando processos que reduzam a geração, reaproveitamento e reciclagem de resíduos.

Finalmente, compete ao Poder Judiciário, aplicar efetivamente as normas ambientais vigentes, enfatizando o princípio da prevenção, o que contribuirá sobremaneira para a internalização das externalidades negativas por parte dos empreendimentos utilizadores de recursos naturais e a adoção de novas medidas que evitem a concretização de danos socioambientais decorrentes do rompimento de barragens de rejeitos da mineração.

\title{
CIVIL LIABILITY OF DAMAGES DUE TO ENVIRONMENTAL DAM DISRUPTION
}

\begin{abstract}
The objective of this study is to analyze the liability for environmental damage resulting from the disruption of dams. Therefore, it will be presented a brief historical account of dam's disruptions in the world. It was analysed the laws of some foreign countries with regard to the liability of environmental damage, in order to provide a systemic view on the current development of the matter. In addition, special focus will be given to the study of environmental liability requirements under Brazilian law, for example, action or omission, environmental damage and causation relation. Finally, we will discuss about the liability for damages resulting from dam disruption in Brazil. Furthermore, it was analysed the laws of brazilian environment protection, concluded that Brazil has a very modern and stringent legislation, which adopted accountability sistem as a protective objective, showing greater similarity to the US law. In contrast, Brazil has no instruments for the damage repair when is disruption of das are inevitable. In this respect, despite the legislative rigor, repair the damage, in Brazil is ineffective and laws should be issued to prevent imediate environmental disasters.
\end{abstract}

Keywords: dam failure; environmental damage; environmental liability; strict liability; sustainable development.

\section{REFERENCIAS}

AMBIENTAL, Geologia. Casos de Estudos: o calapso da barragem de Johnstown (WV, USA, 1889). 2000. Disponível em: <http://w3.ualg.pt/ jdias/GEOLAMB/GAn_Casos/Johnstown/Johnstown.html>. Acesso em: 11 fev. 2017.

ALMEIDA, Humberto Mariano de. Mineração e meio ambiente na Constituição Federal. São Paulo: LTr, 1999.

ANTUNES, Paulo de Bessa. Dano ambiental: uma abordagem conceitual. Rio de Janeiro: Lumen Juris, 2000.

Direito Ambiental. 12. ed. Rio de Janeiro: Lumen Juris, 2010.

ARGENTINA. Constituição Nacional. Disponível em:

<http://www.ppn.gov.ar/sites/default/files/Constitución\%20Nacional.pdf>. Acesso em: 22 mai. 2016 
Ley Nacional 25.675. Ley General del Ambiente. Disponível em: <http://www2.medioambiente.gov.ar/mlegal/marco/ley25675.htm>. Acesso em: 22 mai. 2016.

ATHIAS, Jorge Alex Nunes. Responsabilidade civil e meio ambiente: breve panorama do direito brasileiro. In: Em dano ambiental: prevenção, reparação e repressão. São Paulo: Revista dos Tribunais, 1993.

AZEVEDO, Álvaro Villaça. Teoria geral das obrigações. 5 ed. São Paulo: Revista dos Tribunais, 1994.

BARACHO JÚNIOR, José Alfredo de Oliveira. Responsabilidade civil por dano meio ambiente. Belo Horizonte: Del Rey, 2000.

BARROSO, Lucas Abreu. A obrigação de indenizar e a determinação da responsabilidade civil por dano ambiental. Rio de Janeiro: Forense, 2006.

BRASIL. Constituição da República Federativa do Brasil, de 5 de outubro de 1988. Diário Oficial da República Federativa do Brasil. 5 out. 1988. Disponível em: <http://www.planalto.gov.br/ccivil_03/constituicao/constituicao.htm>. Acesso em: 12 mai. 2016.

Lei n. 6.938, de 31 de agosto de 1981. Dispõe sobre a Política Nacional do Meio Ambiente, seus fins e mecanismos de formulação e aplicação, e dá outras providências. Disponível em: <http://www.planalto.gov. br/ccivil_03/leis/L6938.htm>. Acesso em: 12 mai. 2016.

Lei n. 10.406, de 10 de janeiro de 2002. Institui o Código Civil. Disponível em: <http://www.planalto.gov.br/ccivil_03/leis/2002/110406.htm>. Acesso em: 17 mai. 2016.

COELHO, Fábio Ulhoa. Curso de direito civil: obrigações. Responsabilidade civil. 3 ed. Vol. 2. Sao Paulo: Saraiva, 2009.

CARMO, José Antunes do. Grandes barragens: vulnerabilidades e riscos. 2013. Disponível em: <http://www.uc.pt/fluc/depgeo/Publicacoes/livro_homenagem_FRebelo/441_461>. Acesso em: 22 mai. 2016.

CATALÁ, Lucia Gomis. Responsabilidad por daños al medio ambiente. Pamplona: Aranzadi, 1998.

$\mathrm{CBH}$, Rio das Velhas. Danos causados pelo rompimento da barragem de Mariana preocupam o CBH Rio da Velhas. 2015. Disponível em: <http://cbhvelhas.org.br/noticias/danos-causados-pelo-rompimento-dabarragem-de-mariana-preocupam-o-cbh-rio-das-velhas/>. A

cesso em: 11 fev. 2017.

DIAS, José de Aguiar. Da responsabilidade civil. 10 ed. Rio de Janeiro: Forense, 1997.

DINIZ, Maria Helena. Responsabilidade civil por dano ao meio ambiente. In: NERY, Rosa Maria de Andrade, DONNINI, Rogério. Responsabilidade Civil: Estudos em homenagem ao professor Rui Geraldo Camargo viana. Sa o Paulo: Revista dos Tribunais, 2009.

ARENDHT, Hannah. A condição humana. 10 ed. São Paulo: Forense Universitária, 2000.

IBAMA. Manual de recuperação de áreas degradadas pela mineração: técnicas de revegetação. Brasília: IBAMA, 1990. 
INSTITUTO BRASILEIRO DO MEIO AMBIENTE E DOS RECURSOS NATURAIS RENOVÁVEIS. Laudo técnico preliminar: impactos ambientais decorrentes do desastre envolvendo o rompimento da barragem de Fundão, em Mariana, Minas Gerais, nov. 2015. Disponível em: <http://www.ibama.gov.br/phocadownload/noticias_ambientais/laudo_tecnico_preliminar.pdf >. Acesso em: 23 mai. 2016.

JONES, Carol Adaire. Avaliação da perda pública causada por danos aos recursos naturais. Revista de Direito Ambiental. São Paulo, n. 4, out/dez 1996.

KRELL, Andreas Joachim. Concretização do Dano Ambiental: algumas objeções à teoria do risco integral. Direitos \& Deveres. Revista do Centro de Ciências Jurídicas/CJUR da Universidade Federal de Alagoas/UFAL. Maceió. Imprensa Universitárias, julho - dezembro, 1/8-38. 1997, p. 23-37.

LEITE, José Rubens Morato. Dano Ambiental: do individual ao coletivo extrapatrimonial: teoria e prática. 4. ed. Sa o Paulo: Editora Revista dos Tribunais, 2011.

LEMOS, Patrícia Faga Iglecias. Direito Ambiental: Responsabilidade Civil e Proteção ao Meio Ambiente. 2. ed. São Paulo: Revista dos Tribunais, 2008.

LIMARDI, Gianluca; SACCO, Sonia. Danno ambientale e rischio inquinamento: responsabilita civile e aspetti gestionali. 2011. Disponível em: <http://studiolegalelimardiapps-land1.net/wpcontent/uploads/2015/09/lucca_2011.pdf.>. Acesso em: 20 mai. 2016.

MAZEAUD; MAZEAUD. Traité théorique et pratique de la responsabilité civile, délictuelle et contractuelle. 3 ed. Paris: L. G. D. J. Tomo 1, n. 36, 2013.

PEREIRA, Caio Mário da Silva. Responsabilidade Civil. Rio de Janeiro: Forense, 1990.

MILARÉ, Édis. Direito do ambiente: a gestão ambiental em foco. 7 ed. São Paulo: Revista dos Tribunais, 2011.

MIRRA, Álvaro Luiz Valery. Ação civil pública e reparação de dano do meio ambiental. São Paulo: Juarez de Oliveira, 2003.

PORFÍRIO JUNIOR, Nelson de Freitas. Responsabilidade do Estado em face do Dano Ambiental. São Paulo: Malheiros Editores, 2002.

PEREIRA, Caio Mário da Silva. Responsabilidade Civil. Rio de Janeiro: Forense, 1990.

Quebec. Loi sur la Qualité de l'Environnement - LQE. Disponível em: $<$ http://legisquebec.gouv.qc.ca/fr/showDoc/cs/Q-2?\&digest=>. Acesso em: 20 abr. 2016.

SAMPAIO, Francisco José Marques. Responsabilidade civil e reparação de danos ao meio ambiente. 2. Ed. Rio de Janeiro: Lumen Juris, 1998.

SIRVINSKAS, Luís Paulo. Manual de Direito Ambiental. 4. ed., rev. atualizada e ampliada. São Paulo: Saraiva, 2006.

SOARES, Guido Fernando Silva. Direito Internacional do Meio Ambiente: emergência, obrigações e 
responsabilidades. São Paulo: Atlas, 2001.

STEIGLEDER, Annelise Monteiro. Responsabilidade Civil Ambiental: as Dimensões do Dano Ambiental no Direito Brasileiro. 2. ed. Porto Alegre: Livraria do Advogado Editora, 2011.

STOCO, Rui. Tratado de responsabilidade civil: doutrina e jurisprude`ncia. 7. ed., rev. ampl. e atual. São Paulo: Revista dos Tribunais, 2007.

Trabalho enviado em 10 de setembro de 2016. Aceito em 04 de março de 2017. 